\title{
Estimation of Source Rupture Process and Strong Ground Motion Simulation of the 2002 Denali, Alaska, Earthquake
}

\section{AUTHOR(S):}

Asano, Kimiyuki; Iwata, Tomotaka; Irikura, Kojiro

\section{CITATION:}

Asano, Kimiyuki ... [et al]. Estimation of Source Rupture Process and Strong Ground Motion Simulation of the 2002 Denali, Alaska, Earthquake. Bulletin of the Seismological Society of America 2005, 95(5): 1701-1715

ISSUE DATE:

2005-10-01

URL:

http://hdl.handle.net/2433/209747

\section{RIGHT:}

This copy is for distribution only by the authors of the article and their institutions in accordance with the Open Access Policy of the Seismological Society of America. 


\section{Bulletin of the Seismological Society of America}

This copy is for distribution only by

the authors of the article and their institutions in accordance with the Open Access Policy of the Seismological Society of America.

For more information see the publications section of the SSA website at www.seismosoc.org

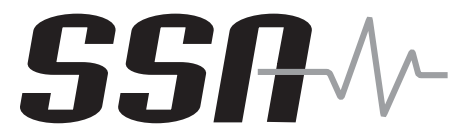

The Seismological Society of America

400 Evelyn Ave., Suite 201

Albany, CA 94706-1375

(510) 525-5474; FAX (510) 525-7204

www.seismosoc.org 


\title{
Estimation of Source Rupture Process and Strong Ground Motion Simulation of the 2002 Denali, Alaska, Earthquake
}

\author{
by Kimiyuki Asano, Tomotaka Iwata, and Kojiro Irikura
}

\begin{abstract}
A $M_{\mathrm{W}} 7.9$ inland crustal earthquake occurred in the Denali fault system, Alaska, on 3 November 2002 at 22:12 (UTC). In this study, we estimated the source process of the 2002 Denali earthquake by a multiple time-window linear kinematic waveform inversion using strong motion and Global Positioning System (GPS)measured static displacement data.

The obtained source model could explain both the observed strong motion waveforms and GPS-measured static displacements. Large slips on the fault plane are observed at approximately $80-90 \mathrm{~km}$ and $150-200 \mathrm{~km}$ east from the hypocenter. These features are consistent with the observed surface rupture distribution and the other inversion results obtained using teleseismic body waves. We also observed some portions of the whole fault with a local rupture propagation velocity of more than $4.0 \mathrm{~km} / \mathrm{sec}$ that exceeded the shear-wave velocity of the source region. The relation between the rupture area and seismic moment of this earthquake seems to follow the bilinear $L$-model scaling rather than the self-similar source scaling model. The combined area of asperities is somewhat smaller than that expected from the empirical scaling relationship with seismic moments developed by compiling inverted source models.

Finally, we conducted a forward ground motion simulation using the finite difference method to estimate the influence of the heterogeneous source process obtained here on the spatial distribution of strong ground motions. The calculated ground motions are relatively large above and around the large slip areas and also in the region east of the fault area because of the forward directivity effect of unilateral rupture propagation.
\end{abstract}

\section{Introduction}

An earthquake occurred in the Denali fault system, Alaska, on 3 November 2002 at 22:12:41.5 (UTC). The Alaska Earthquake Information Center (AEIC) had determined the location of its hypocenter to be $63.5141^{\circ} \mathrm{N}$ and $147.4529^{\circ} \mathrm{W}$ at a depth of $4.2 \mathrm{~km}$ (Ratchkovski et al., 2002). Its moment magnitude, determined by the Harvard University CMT project (Ekström et al., 2005), was 7.9. It was the largest inland strike-slip crustal earthquake in North America since the 1857 Fort Tejon, California, earthquake $\left(M_{\mathrm{W}}\right.$ 7.9). It is quite important to study the source models of such great earthquakes in order to evaluate ground motions brought by these great inland crustal earthquakes. However, prior to this earthquake, there had been no historical great earthquake with sufficient strong ground motion records. The 2002 Denali, Alaska, earthquake has an important role to play in the advancement of studies on the source modeling of great inland crustal earthquakes.

The Denali fault system extends for more than $2000 \mathrm{~km}$ across southcentral Alaska, Yukon Territory, northern Brit- ish Columbia, and southeastern Alaska (Lanphere, 1978). St. Amand (1957) named the fault system the Denali fault system. Individual fault segments of the fault system were named or redefined by Grantz (1966). Lanphere (1978) stated that the Denali fault system exhibited Holocene displacement only on the McKinley and Totschunda segments and on the western part of the Shakwak segment. The mean Holocene displacement rates on the McKinley segment are 10 to $20 \mathrm{~mm} / \mathrm{yr}$ (Hickman et al., 1977). The right-lateral slip rate on the Totschunda fault has also been estimated to have been 10 to $20 \mathrm{~mm} / \mathrm{yr}$ during the Holocene (Plafker et al., 1977). Savage and Lisowski (1991) mentioned an absence of evidence of Holocene slip on the eastern portion of the Denali fault from $143^{\circ} \mathrm{W}$.

The surface rupture generated by this event has been surveyed for approximately $300 \mathrm{~km}$ (Fuis and Wald, 2003). The rupture started from the Susitna Glacier fault, propagated to the east along the McKinley segment and the western portion of the Shakwak segment of the Denali fault, and 
terminated at the Totschunda fault. The source processes have also been examined using teleseismic data (Kikuchi and Yamanaka, 2002; Ji et al., 2003; Ozacar et al., 2003), strong-motion data (Frankel, 2004), geodetic data (Hreinsdóttir et al., 2003; Wright et al., 2004), and combinations of several kinds of data (Dreger et al., 2004; Oglesby et al., 2004).

Strong-motion records of this event were obtained by the United States Geological Survey (USGS), the University of Alaska at Fairbanks (UAF), and the Alyeska Pipeline Service Company (Alyeska). These data have been distributed through the National Strong-Motion Program operated by the USGS (Martirosyan et al., 2004). Continuous and campaign GPS (Global Positioning System) data were obtained and processed by Hreinsdóttir et al. (2003).

In this study, a source process of this event is estimated by the multiple time-window linear kinematic waveform inversion method using strong motion waveforms and static GPS-measured horizontal displacements. Strong-motion waveforms can retrieve information on the temporal and spatial process of the rupture. However, since no strong-motion station in the eastern region of the source area is available, the spatial resolution of the eastern part of the fault plane may be relatively poorer than that of the western part (Fig. 1). There is a possibility that the GPS data could improve the spatial resolution of the final slip distribution. The combined use of strong-motion recordings with other data sets, such as teleseismic observations or geodetic measurements, can generally increase the period band covered by the inversion (Graves and Wald, 2001). Subsequently, some remarkable features on the inverted source process of this event are discussed. Finally, a ground motion simulation that employs the finite difference method will be conducted to evaluate the influence of the heterogeneous source process on the near-source ground motions.

Estimation of the Source Rupture Process using the Multiple Time-Window Linear Kinematic Waveform Inversion Method

\section{Data}

Strong-motion records obtained at 10 stations around the fault area are used in the waveform inversion (Fig. 1 and Table 1). Stations 2784 and 8022 belong to the USGS. Stations FA02 and K2-06 belong to the Geophysical Institute of the UAF. Stations R109 and Carlo are temporary stations installed after the 23 October 2002 Nenana Mountain earthquake $\left(M_{\mathrm{s}} 6.7\right)$ by the UAF. Stations PS08, PS09, PS10, and PS11 are attached to pump stations of the Trans Alaska Pipeline System (TAPS) operated by Alyeska. Table 1 provides a list of strong motion stations used in this study.

All the original strong-motion data are digitally recorded acceleration data. The original data were sampled at $200 \mathrm{~Hz}$, except at R109 and Carlo, where the original data were sampled at $100 \mathrm{~Hz}$. The acceleration data were inte-

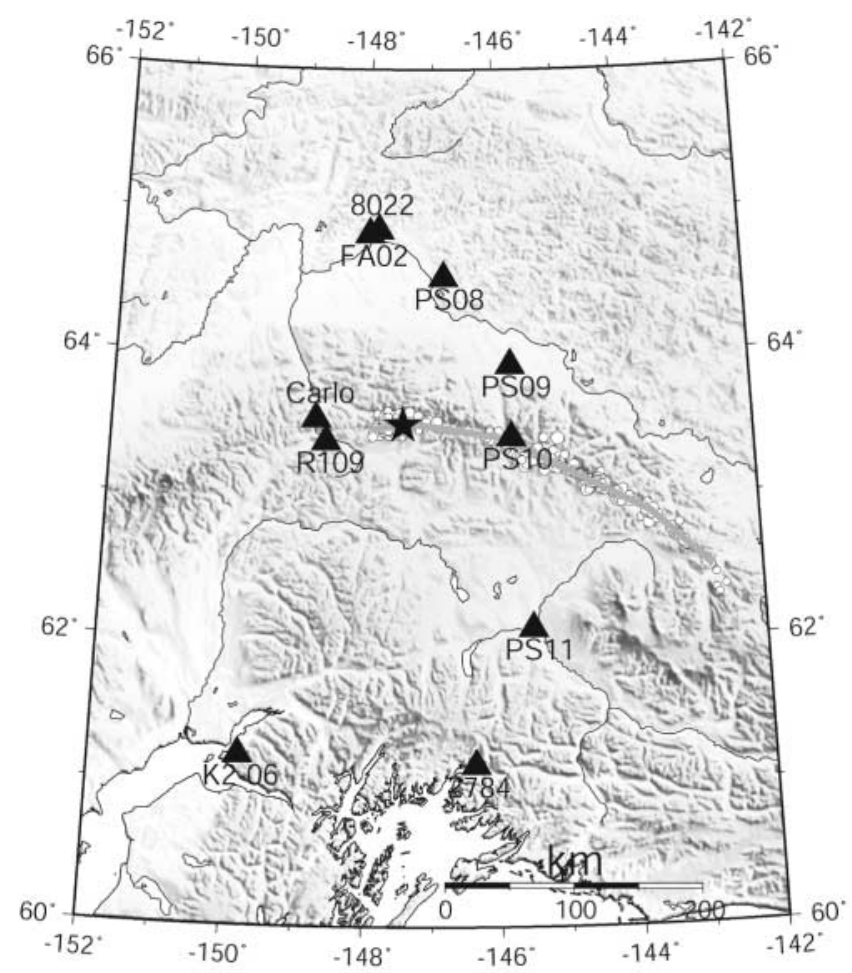

Figure 1. Map showing strong motion stations (solid triangles) used in this study and aftershocks (open circles). The epicenter of the 2002 Denali earthquake determined by the Alaska Earthquake Information Center (AEIC) is indicated by the solid star. The locations of aftershocks were also determined by AEIC (Ratchkovski et al., 2003). The bold lines show the projection of the source fault assumed for the waveform inversion analysis.

Table 1

Strong Motion Stations Used in the Waveform Inversion

\begin{tabular}{|c|c|c|c|}
\hline Station & $\begin{array}{l}\text { Latitude } \\
\text { (deg) }\end{array}$ & $\begin{array}{l}\text { Longitude } \\
\quad(\mathrm{deg})\end{array}$ & Location \\
\hline 2784 & 61.1302 & -146.3547 & Valdez City Hall \\
\hline 8022 & 64.8735 & -147.8614 & $\begin{array}{c}\text { Fairbanks; Geophysical } \\
\text { Observatory, CIGO }\end{array}$ \\
\hline FA02 & 64.8455 & -148.0089 & Fairbanks; Ester Fire Station \\
\hline K2-06 & 61.191 & -149.822 & Anchorage; K2-06 \\
\hline R109 & 63.3953 & -148.6468 & R109 (temporary) \\
\hline Carlo & 63.5514 & -148.8093 & Carlo (temporary) \\
\hline PS08 & 64.5431 & -146.8194 & TAPS Pump Station \#8 \\
\hline PS09 & 63.9311 & -145.7681 & TAPS Pump Station \#9 \\
\hline PS 10 & 63.4239 & -145.7658 & TAPS Pump Station \#10 \\
\hline PS11 & 62.0881 & -145.4808 & TAPS Pump Station \#11 \\
\hline
\end{tabular}

grated into velocity in the time domain and bandpass filtered by a Chebyshev filter between 0.1 and $0.5 \mathrm{~Hz}$ for the Alyeska stations and between 0.05 and $0.5 \mathrm{~Hz}$ for the others, because the original analog signals from the sensor at Alyeska's stations were bandpass filtered between 0.1 and $40 \mathrm{~Hz}$ by a pair of cascaded two-pole Butterworth filters prior to digitization by a PC-based recording system in the pump station facility 
(Ellsworth et al., 2004). Subsequently, the waveform data were resampled at $5 \mathrm{~Hz}$. We inverted $100 \mathrm{sec}$ of the $S$-wave portion, except for R109, Carlo, PS08, and PS10, where the length of available time histories is shorter than $100 \mathrm{sec}$. For these stations, we took the data length as long as possible.

Twenty-five GPS stations, listed in Table 2, were chosen from the data set of Hreinsdóttir et al. (2003). Hreinsdóttir et al. (2003) estimated the coseismic displacement by merging the averaged solution for 4 days prior to and 4 days following the earthquake for permanent stations and certain campaign stations, and fitting a line plus offset to the station time series using the first 3 days of postearthquake measurements at each site for the other campaign stations. They processed the GPS data in the International Terrestrial Reference Frame 1997 (ITRF97) (Boucher et al., 1999) using about 15 global reference sites. The processing of GPS data is described by Hreinsdóttir et al. (2003). The static horizontal displacements are used in the inversion analysis.

\section{Estimation of Rupture Propagation Velocity}

from the Observed Waveforms

Generally, the rupture propagation velocity of an earthquake does not exceed the shear-wave velocity in the source region. However, previous theoretical studies of finite stress shear crack propagation (e.g., Burridge, 1973; Andrews, 1976; Das and Aki, 1977) have demonstrated that rupture propagation velocities in excess of the shear-wave velocity might be possible when cohesive stresses are sufficiently low. Day (1982) extended these two-dimensional results to the three-dimensional problem of mixed-mode shear crack propagation. It was demonstrated that supershear rupture velocity could be predicted for low-cohesion cracks in directions in which in-plane crack motion dominated, while subshear velocity could be predicted for cracks in directions in which antiplane crack motion dominated. The existence of supershear rupture velocities in actual large earthquakes has been reported in the case of the 1979 Imperial Valley earthquake (e.g., Olson and Apsel, 1982; Archuleta, 1984), the 1992 Landers earthquake (e.g., Wald and Heaton, 1994), the 1999 Kocaeli, Turkey, earthquake (e.g., Ellsworth and Çelebi, 1999; Bouchon et al., 2000; Sekiguchi and Iwata, 2002), and the 2001 Kunlunshan, China, earthquake (Bouchon and Vallée, 2003). These large earthquakes occurred on long-strike fault systems and had tectonic settings similar to those of the Denali fault system. Therefore, it is indispensable for understanding the rupture dynamics of the 2002 Denali earthquake to examine the possibility of a supershear rupture during the event.

Among the available strong-motion stations, the Alyeska pump station 10 (PS10) is located at a distance of approximately $3 \mathrm{~km}$ from the nearest surface rupture. According to the reprocessing of the PS10 record by Ellsworth et al. (2004), growth of the fault-parallel displacement is almost monotonic with a peak displacement of $2.56 \mathrm{~m}$ and a permanent displacement of $2.30 \mathrm{~m}$. That fault-parallel dis-
Table 2

GPS Stations Used in the Combined Inversion

\begin{tabular}{lccc}
\hline Station & $\begin{array}{c}\text { Latitude } \\
(\mathrm{deg})\end{array}$ & $\begin{array}{c}\text { Longitude } \\
(\mathrm{deg})\end{array}$ & $\begin{array}{c}\text { Amplitude } \\
(\mathrm{m})\end{array}$ \\
\hline TAZL & 62.0799 & -145.4339 & 0.1164 \\
GNAA & 62.1124 & -145.9702 & 0.0724 \\
TLKA & 62.3077 & -150.4203 & 0.0284 \\
7297 & 62.6880 & -145.4261 & 0.3145 \\
MEN & 62.9095 & -143.7953 & 3.1083 \\
PAXS & 62.9673 & -145.4517 & 0.6706 \\
LOG & 63.0226 & -143.3454 & 1.1268 \\
FCRK & 63.0907 & -145.4753 & 0.9972 \\
DH97 & 63.2651 & -147.8551 & 0.1948 \\
M110 & 63.3055 & -148.1870 & 0.1750 \\
STRI & 63.3334 & -142.9531 & 0.2975 \\
SSWB & 63.3413 & -149.0902 & 0.0650 \\
L2C6 & 63.3828 & -148.8662 & 0.0658 \\
CGLO & 63.3883 & -148.9496 & 0.0677 \\
HIW4 & 63.4643 & -148.8073 & 0.0539 \\
PANA & 63.4838 & -148.8204 & 0.0549 \\
ATT & 63.5025 & -145.8472 & 1.5026 \\
0999 & 63.6650 & -142.2748 & 0.1309 \\
DNLY & 63.6951 & -145.8876 & 0.6185 \\
GRNR & 63.8358 & -148.9783 & 0.0574 \\
BSB4 & 63.9065 & -145.7891 & 0.2939 \\
2999 & 64.0287 & -142.0761 & 0.1217 \\
NENA & 64.5794 & -149.0798 & 0.0455 \\
CLGO & 64.8738 & -147.8605 & 0.0569 \\
FAIR & 64.9780 & -147.4992 & 0.0573 \\
\hline
\end{tabular}

The amplitudes of observed static displacements were obtained from Hreinsdóttir et al. (2003).

placement time history could represent the fault dislocation near PS10. By comparing the observed and calculated travel time of the fault-parallel phase at PS10, the average rupture propagation velocity between the starting point of the rupture and a point on the fault in front of PS10 was estimated to be approximately $2.8 \mathrm{~km} / \mathrm{sec}$ (Fig. 2). However, this does not eliminate the possibility of supershear rupture on a certain portion of the fault plane.

\section{Methodology of Waveform Inversion}

Employing the multiple time-window linear kinematic waveform inversion method used by Sekiguchi et al. (2000) and Sekiguchi and Iwata (2002), we inverted velocity waveforms and GPS-measured static displacements to obtain a faulting process. The methodology, which basically follows the approach by Hartzell and Heaton (1983), has been explained in detail by Sekiguchi et al. (2000).

The dislocation at an earthquake fault is related to the displacement at the surface via the representation theorem (Maruyama, 1963; Burridge and Knopoff, 1964),

$$
u_{n}(\mathbf{x}, t)=\int d \tau \iint_{\Sigma} \Delta u_{i}(\xi, \tau) c_{i j k l}(\xi) n_{j} G_{n k, l}(\mathbf{x}, t-\tau ; \xi, 0) d \Sigma
$$

where $u_{n}(\mathbf{x}, t)$ is the $n$th component of the displacement at point $\mathbf{x}$ at time $t, \Delta u_{i}(\xi, \tau)$ is the dislocation in the $i$ th direc- 


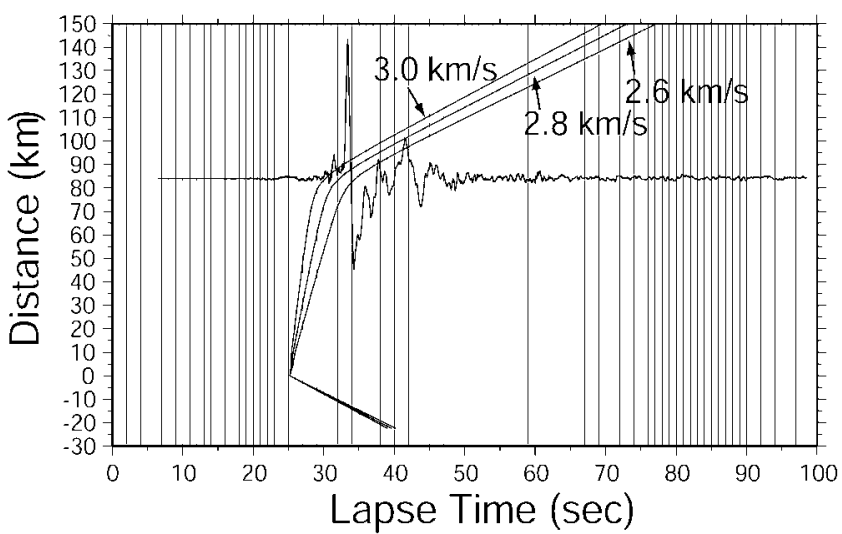

Figure 2. $S$-phase arrival time curves at PS10 from each subfault with a uniform rupture velocity. The observed east-west velocity waveform at PS10 is also shown. Cases for a rupture velocity of 2.6, 2.8, and $3.0 \mathrm{~km} / \mathrm{sec}$ are shown. To explain the phase corresponding to the dislocation of the fault, the average rupture propagation velocity between the hypocenter and the nearest part from PS10 was estimated to be $2.8 \mathrm{~km} / \mathrm{sec}$.

tion at point $\xi$ at time $\tau, c_{i j k l}$ is the elastic constant tensor, $G_{n k, l}$ is the spatial derivative of Green's tensor representing the $n$th component of the displacement response at point $\mathbf{x}$ to a point dislocation in the $k$ th direction on a plane normal to the $l$ th direction at $\xi, \Sigma$ is the fault plane surface, and $n_{j}$ is the $j$ th component of $\mathbf{n}$, the vector normal to $\Sigma$. To obtain the velocity $\dot{u}_{n}(\mathbf{x}, t)$ at point $\mathbf{x}$ at time $t$, equation (1) can be rewritten as

$$
\dot{u}_{n}(\mathbf{x}, t)=\int d \tau \iint_{\Sigma} \Delta u_{i}(\xi, \tau) c_{i j k l}(\xi) n_{j} \dot{G}_{n k, l}(\mathbf{x}, t-\tau ; \xi, 0) d \Sigma,
$$

where $\dot{G}_{n k, l}$ is the temporal derivative of $G_{n k, l}$.

Fault planes are discretized into $n f$ smaller subfaults. The slip history on each subfault is discretized into several $(\mathrm{ntm})$ time windows. Subsequently, equation (2) is discretized as

$$
\begin{array}{r}
\dot{u}_{n}(\mathbf{x}, t)=\sum_{i t m=1}^{n t m} \sum_{i s=1}^{n s} \sum_{i f=1}^{n f} m(\text { if }, \text { is, itm }) \int \Delta u_{\text {unit }_{i s}}\left(\tau-\Delta t_{\text {trig }}\right) \\
\times c_{i(i s) j k l}(\xi(\text { if })) n_{j} \dot{G}_{n k, l}(\mathbf{x}, t-\tau ; \xi(\text { if }), 0) d \tau,
\end{array}
$$

where

$$
\Delta t_{\text {trig }}=\frac{R_{i f}}{V_{r}}+\Delta t w \cdot(i t m-1) .
$$

Here, $m$ (if, is, itm) is the amount of slip in the isth direction at the itm th time window on the ifth subfault, $n s$ is the number of slip direction (here, $n s$ is 2), $R_{\text {if }}$ is the hypocentral distance of the ifth subfault, $\Delta t w$ is the interval of time windows, and $\Delta u_{\text {unit }_{i s}}$ is the unit slip function. $V_{r}$ is the first time- window front propagation velocity (the propagation velocity of the virtual fastest rupture front).

The discretized observational equations (3) in vector form for strong motion waveforms are

$$
\mathbf{G m}=\mathbf{d},
$$

and,

$$
\begin{aligned}
\mathbf{d}_{p} & =\dot{u}_{n}(\mathbf{x}, t), \\
\mathbf{m}_{q} & =m(i f, i s, i t m), \\
\mathbf{G}_{p q} & =\int \Delta u_{\text {unit }_{i s}}\left(\tau-\Delta t_{\text {trig }}\right) c_{i(i s) j k l}(\xi(\text { if })) n_{j} \dot{G}_{n k, l} \\
& (\mathbf{x}, t-\tau ; \xi(\text { if }), 0) d \tau, \\
p & =(n-1) n t+(r-1) \Delta t, \\
q & =(i t m-1) n s \cdot n f+(i s-1) n f+i f, \\
1 & \leq r \leq n t, \quad 1 \leq n \leq n c m p, \quad 1 \leq \text { if } \leq n f, \\
& 1 \leq i s \leq n s, \quad 1 \leq i t m \leq n t m,
\end{aligned}
$$

where $n t$ is the number of data points for a component, $n \mathrm{cmp}$ is the number of components, and $\Delta t$ is the sampling interval of data. Each component of strong motions at individual stations is normalized to the maximum value.

For GPS-measured displacement data, only the final displacements should be considered. Observational equations in vector form for static displacements at the GPS stations are

$$
\mathbf{H m}=\mathbf{d}_{G} .
$$

Here,

$$
\begin{aligned}
& \mathbf{d}_{G}=\lim _{t \rightarrow+\infty} u_{n}(\mathbf{x}, t), \\
& \mathbf{m}_{q}=m(\text { if, is, itm }), \\
& \mathbf{H}_{q}=\lim _{t \rightarrow+\infty} \int \Delta u_{\text {unit }_{i s}}\left(\tau-\Delta t_{\text {trig }}\right) c_{i(i s) j k l}(\xi(i f)) n_{j} G_{n k, l} \\
& \quad(\mathbf{x}, t-\tau ; \xi(\text { if }), 0) d \tau, \\
& q=(i t m-1) n s \cdot n f+(i s-1) n f+i f, \\
& 1 \leq n \leq n c m p, \quad 1 \leq i f \leq n f, \quad 1 \leq i s \leq n s, \\
& \quad 1 \leq i t m \leq n t m .
\end{aligned}
$$

Wald and Graves (2001) mention that no individual station weight should be used for the geodetic data. Their premise is that normalization or relatively small differences in observed and predicted amplitude leads to instability if individual components are given equal weight. This is because the amplitude of individual components of GPS data can be close to zero even in the near-source area. Therefore, static GPS-measured displacements were not normalized in this study.

A spatiotemporal smoothing constraint introduced by Sekiguchi et al. (2000) is also employed as

$$
\mathbf{S m}=0
$$


This is assigned to reduce instability or complexity beyond that which can be resolved by data based on inspection that slips that are spatially and temporarily close together should be similar.

The observational equations (5) and (6) and the smoothing constraint equations (7) are combined as

$$
\left(\begin{array}{c}
\mathbf{G} \\
\lambda_{H} \mathbf{H} \\
\lambda_{S} \mathbf{S}
\end{array}\right) \mathbf{m}=\left(\begin{array}{c}
\mathbf{d} \\
\mathbf{d}_{G} \\
0
\end{array}\right),
$$

where $\lambda_{H}$ is the hyperparameter describing the relative weight of the GPS data against the strong-motion data, and $\lambda_{S}$ is the hyperparameter describing the relative strength of the smoothing constraint equations against the observational equations. Model parameters $\mathbf{m}$ should be solved to minimize $\left\|(\mathbf{G m}-\mathbf{d})+\lambda_{H}\left(\mathbf{H m}-\mathbf{d}_{G}\right)+\lambda_{S} \mathbf{S m}\right\|$, where $\|*\|$ denotes the $L_{2}$-norm. We solved this linear least-squares problem with rake angle constraints using the nonnegative least-squares algorithm by Lawson and Hanson (1974). The rake angle constraints used are described later.

Appropriate first time-window front propagation velocity $V_{r}$ is selected so as to minimize the residual of data fitting. To select the appropriate value of the hyperparameters $\lambda_{H}$ and $\lambda_{S}$, Akaike's Bayesian Information Criterion (ABIC), proposed by Akaike (1980), is employed following Sekiguchi et al. (2000). When the value of ABIC is lowest, a solution obtained under that situation is the most appropriate for our problem. ABIC under two individual prior constraints is defined as

$$
\begin{aligned}
A B I C= & \left(M_{G}+M_{H}+M_{S}-N\right) \log \left(\|\mathbf{d}-\mathbf{G m}\|^{2}\right. \\
& \left.+\lambda_{H}^{2}\left\|\mathbf{d}_{G}-\mathbf{H m}\right\|^{2}+\lambda_{S}^{2}\|\mathbf{S m}\|^{2}\right) \\
- & 2 M_{H} \log \lambda_{H}-2 M_{S} \log \lambda_{S} \\
& +\log \left\|\mathbf{G}^{T} \mathbf{G}+\lambda_{H}^{2} \mathbf{H}^{T} \mathbf{H}+\lambda_{S}^{2} \mathbf{S}^{T} \mathbf{S}\right\|+C .
\end{aligned}
$$

Here, $N$ is the total number of model parameters, $M_{G}, M_{H}$, and $M_{S}$ are the rank of $\mathbf{G}, \mathbf{H}$, and $\mathbf{S}$, respectively, $\left\|\mathbf{G}^{T} \mathbf{G}+\lambda_{H}^{2} \mathbf{H}^{T} \mathbf{H}+\lambda_{S}^{2} \mathbf{S}^{T} \mathbf{S}\right\|$ represents the absolute value of the determinant of $\left(\mathbf{G}^{T} \mathbf{G}+\lambda_{H}^{2} \mathbf{H}^{T} \mathbf{H}+\lambda_{S}^{2} \mathbf{S}^{T} \mathbf{S}\right)$, and $C$ is a constant term independent of the hyperparameters.

\section{Fault Geometry and Slip Representation}

For the inversion, a fault model that consists of four segments was assumed. This model is based on the aftershock distribution determined by the AEIC (Ratchkovski et al., 2003), surface ruptures (Eberhart-Phillips et al., 2003; Fuis and Wald, 2003), the focal mechanism determined by initial $P$-wave polarities (Ratchkovski et al., 2002), and the centroid moment tensor solution by the Harvard CMT project. The model parameters of fault planes are listed in Table 3. The fault trace is also indicated in Figure 3. The segment
SG represents the Susitna Glacier fault. Segments MK and SW represent the McKinley segment and the western portion of the Shakwak segment of the Denali fault, respectively. Furthermore, segment TC represents the Totschunda fault. The fault planes are divided into subfaults of $4.5 \mathrm{~km} \times 4.5$ $\mathrm{km}$. The total length of the assumed fault planes is 292.5 $\mathrm{km}$. Ratchkovski et al. (2003) relocated more than 4200 aftershocks using permanent and temporal station data, and showed that most aftershocks were located within the upper $7 \mathrm{~km}$ of the crust. However, there were several aftershocks that occurred between 7 and $18 \mathrm{~km}$ depth, so we assumed the width of fault planes to be $18 \mathrm{~km}$. A point source was assumed at the center of each subfault. In this fault model, the shallowest point sources are located at a depth of $2.25 \mathrm{~km}$.

The slip time history of each subfault is expressed by six time windows. The rise time of one time window is 2.0 $\mathrm{sec}$, and the time window interval is $1.0 \mathrm{sec}$. The rake angle is limited from pure-dip to right-lateral slip on the Susitna Glacier fault, and right-lateral $\pm 45^{\circ}$ slip on the Denali and Totschunda faults.

\section{Underground Structure Model and Green's Function}

We assumed a laterally homogeneous underground structure interpreted from the results of the refraction and

Table 3

Model Parameters of Fault Planes Assumed for the Waveform Inversion

\begin{tabular}{ccccc}
\hline Segment & Length $(\mathrm{km})$ & Width $(\mathrm{km})$ & Strike $(\mathrm{deg})$ & Dip (deg) \\
\hline SG & 31.5 & 18.0 & 262 & 48 \\
MK & 72.0 & 18.0 & 279 & 86 \\
SW & 126.0 & 18.0 & 298 & 86 \\
TC & 63.0 & 18.0 & 315 & 86 \\
\hline
\end{tabular}

SG indicates the Susitna Glacier fault. MK and SW indicate the McKinley segment and western portion of the Shakwak segment of the Denali fault, respectively. TC indicates the Totschunda fault. The spatial location of each segment is shown in Figure 3.

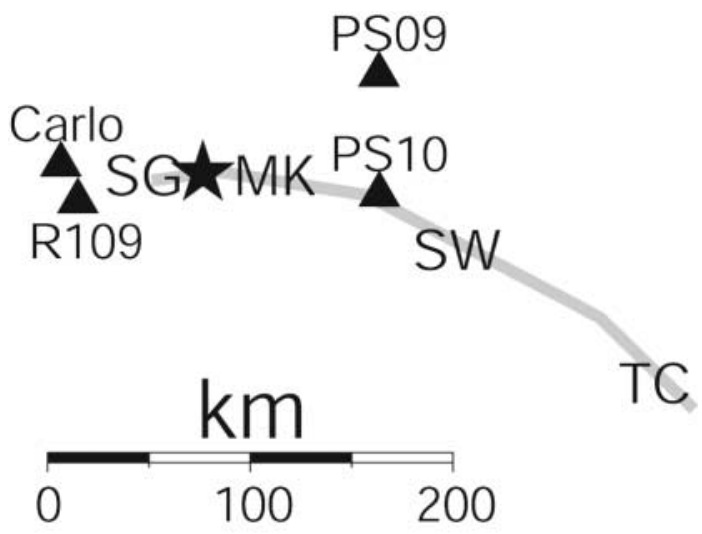

Figure 3. Assumed fault plane model for the waveform inversion analysis. Model parameters of each fault segment are listed in Table 3. 
wide-angle reflection survey by Beaudoin et al. (1992). The same underground structure model was used for all strong motion and GPS stations. The underground structure model used is shown in Table 4. We assumed the minimum shearwave velocity of $2.2 \mathrm{~km} / \mathrm{sec}$ in our velocity structure model. This assumption is based on the results by some seismic profiling studies (Brocher et al., 1991; Beaudoin et al., 1992) showing that the thickness of low-velocity Quaternary deposits with a shear-wave velocity lower than $2.0 \mathrm{~km} / \mathrm{sec}$ is less than a few hundred meters in the Denali fault area. In general, these thin, low-velocity layers do not affect significantly the ground motions in the frequency range we use.

Each Green's function from the center of the subfault to the station was calculated using the discrete wave number method (Bouchon, 1981) together with the reflection transmission matrix method (Kennett and Kerry, 1979). After that, a smoothed ramp function,

$$
f(t)=\frac{M_{0_{e}}}{2 \mu A}\left\{1+\tanh \frac{4\left(t-t_{0} / 2\right)}{t_{0}}\right\},
$$

was convolved with each Green's function in the frequency domain to obtain the basis function or one time window function at the subfault, where $M_{0_{e}}$ is the unit moment, $\mu$ is the rigidity at the subfault, $A$ is the area of the subfault, and $t_{0}$ is the rise time for one time window. Then, they were bandpass filtered and resampled in a manner similar to that of the observed data.

Wald and Graves (2001) proposed and validated utilizing the same wave propagation code used to compute the strong ground motion waveforms for static computations. Following their approach, we calculated the static Green's functions for the GPS stations using the same computation method as with strong ground motions.

\section{Results}

We conducted the waveform inversion analysis allowing a variation of the first time-window front propagation

Table 4

Underground Structure Models to Calculate Green's Functions for the Waveform Inversion

\begin{tabular}{rccccc}
\hline Depth $(\mathrm{m})$ & $V_{P}(\mathrm{~m} / \mathrm{sec})$ & $V_{S}(\mathrm{~m} / \mathrm{sec})$ & $\rho\left(\mathrm{kg} / \mathrm{m}^{3}\right)$ & $Q_{P}$ & $Q_{S}$ \\
\hline 0 & 3800 & 2200 & 2200 & 200 & 100 \\
1000 & 5200 & 3000 & 2600 & 400 & 200 \\
2000 & 5900 & 3400 & 2700 & 600 & 300 \\
10000 & 6250 & 3600 & 2800 & 800 & 400 \\
27000 & 7000 & 4000 & 3000 & 1200 & 600 \\
32000 & 8200 & 4700 & 3200 & 1500 & 750 \\
\hline
\end{tabular}

The model of each layer contains the $P$-wave velocity $\left(V_{P}\right)$, the $S$-wave velocity $\left(V_{S}\right)$, the density $(\rho)$, and the quality factors for the $P$ wave $\left(Q_{P}\right)$ and $S$ wave $\left(Q_{S}\right)$. Depth implies the depth of the top of each layer from the ground surface. velocity between the western and eastern parts of the fault plane. From the result of this analysis, the first time-window front propagation velocity is $2.8 \mathrm{~km} / \mathrm{sec}$ at the $\mathrm{SG}$ and $\mathrm{MK}$ segments and $3.4 \mathrm{~km} / \mathrm{sec}$ at the $\mathrm{SW}$ and TC segments. This suggests that the average rupture propagation velocity changes faster during the rupture. The latter is close to the assumed shear-wave velocity at the main part of the source region. Figure 4 shows how we determined the first timewindow front propagation velocities.

The final slip distribution is mapped in Figure 5a. Figure 6 shows the temporal evolution of the rupture. The rupture continued almost $90 \mathrm{sec}$. Relatively large slip areas are observed at approximately $80-90 \mathrm{~km}$ east and approximately 150-200 km east from the hypocenter. The slip direction

(a)

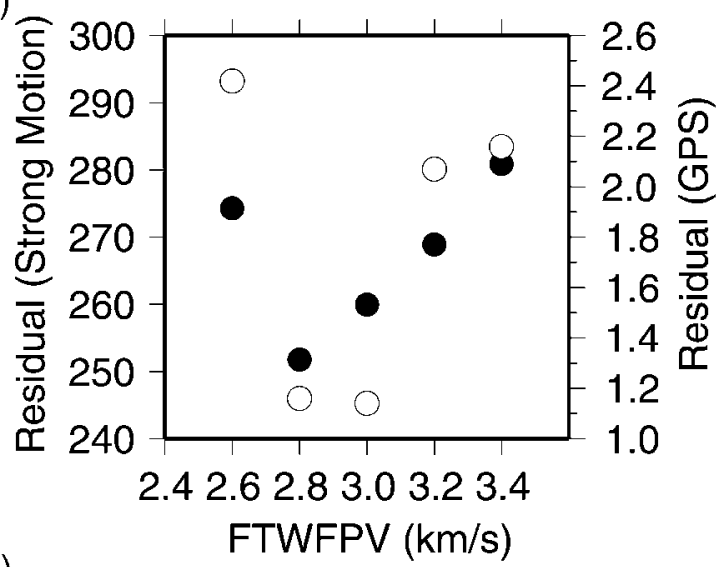

(b)

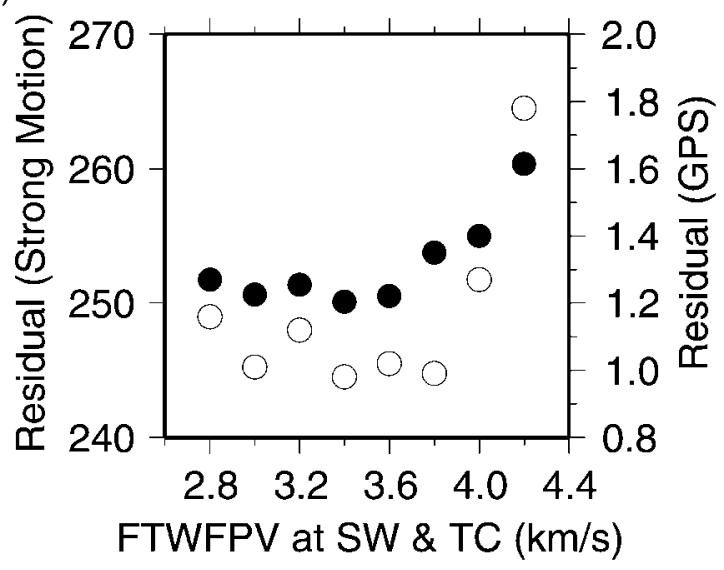

Figure 4. Relationship between the residuals of strong motion (solid circle) and GPS data (open circle) and the first time-window front propagation velocities (FTWFPV). (a) The assumed FTWFPVs are the same for all the segments. In this case, a FTWFPV of 2.8 $\mathrm{km} / \mathrm{sec}$ gives the best solution. (b) We allowed the FTWFPVs of the SW and TC segments to be different from those of the SG and MK segments. The FTWFPVs of the SG and MK segments were fixed at $2.8 \mathrm{~km} / \mathrm{sec}$. In this case, a FTWFPV of $3.4 \mathrm{~km} / \mathrm{sec}$ for the SW and TC segments gives the best solution. 
(a)
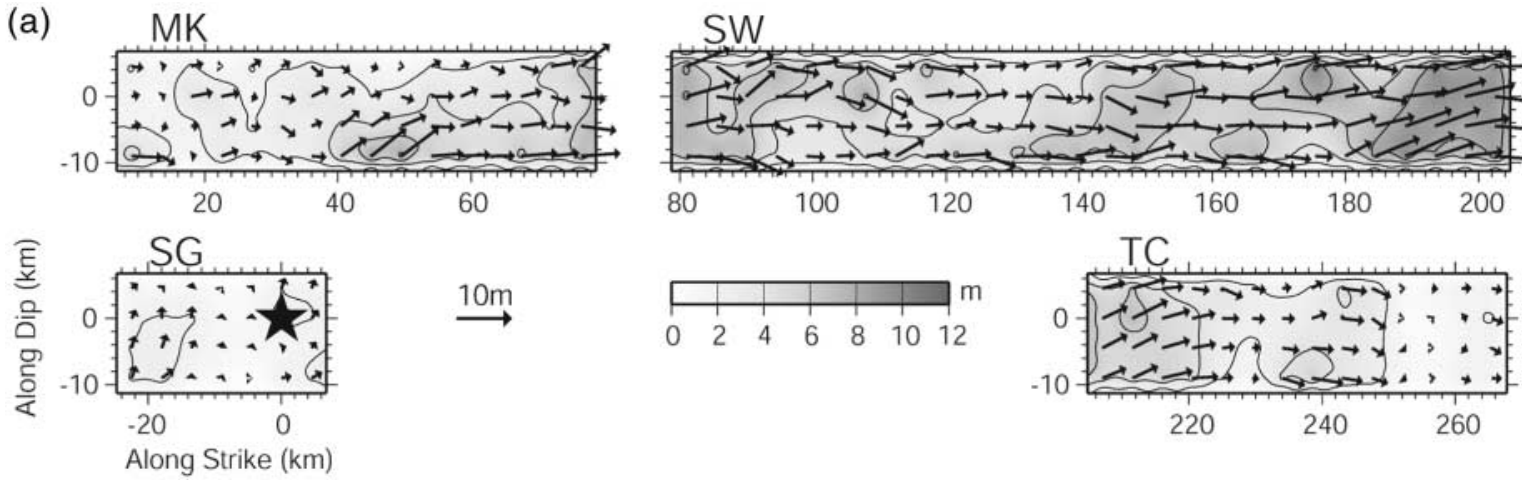

$\stackrel{10 \mathrm{~m}}{\longrightarrow}$

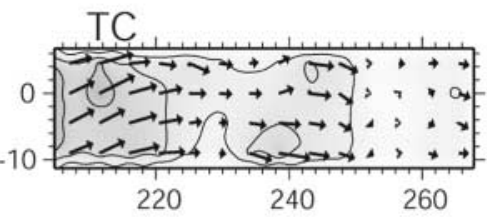

(b)

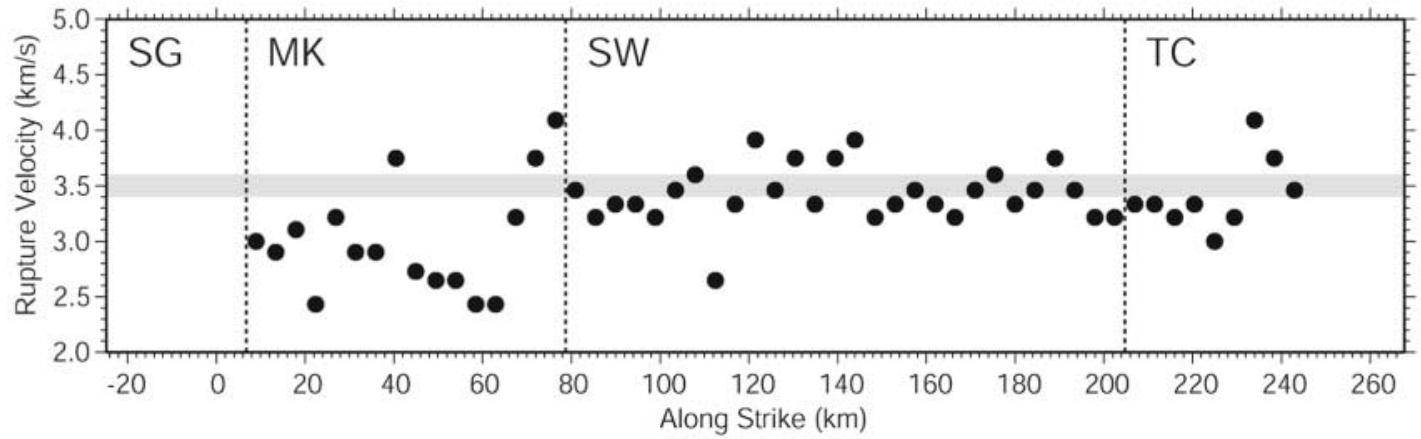

(c)

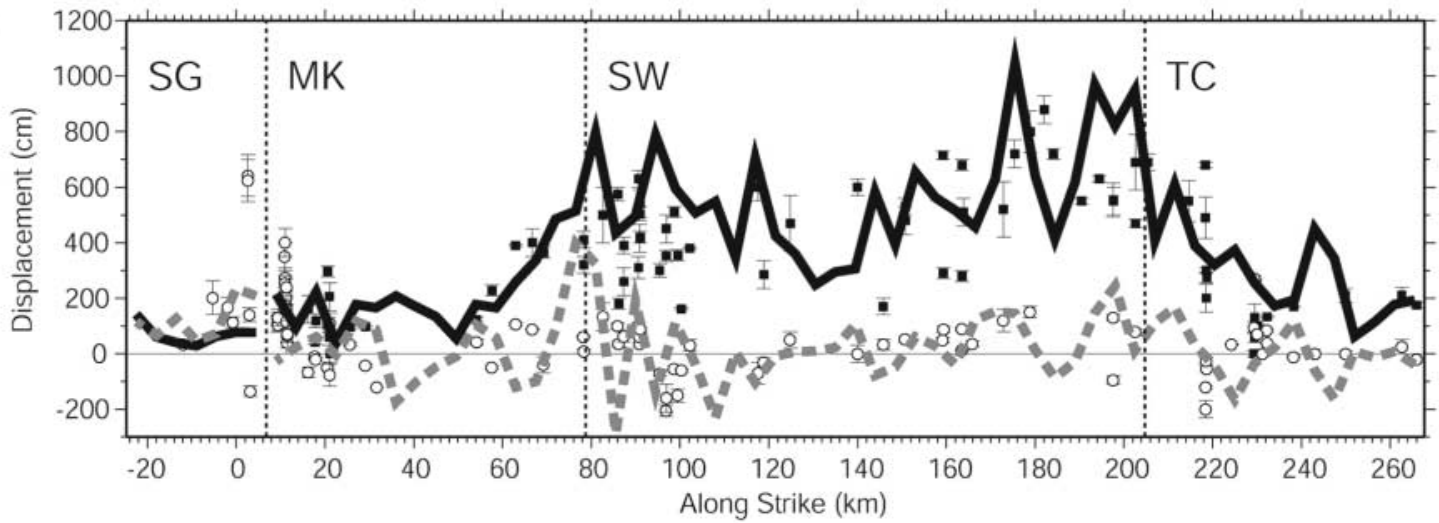

(d)

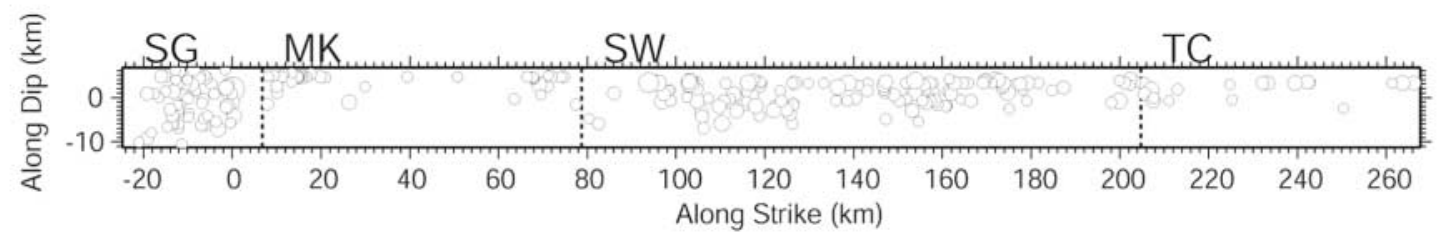

Figure 5. (a) The final slip distribution obtained by the inversion of strong motion and GPS data. The interval between the contours is $2 \mathrm{~m}$. (b) The variation of the rupture velocity along the strike direction. The shear-wave velocity in the source region is indicated by the gray line. (c) Comparison of the slip amount on the shallowest subfaults with surface offsets. Solid squares and open circles with standard deviation bars indicate observed horizontal surface offsets and vertical surface offsets reported by Eberhart-Phillips et al. (2003). Solid and broken curves show the slip amount of the shallowest subfault estimated from the kinematic waveform inversion in the strike and dip direction, respectively. For vertical slip, positive values denote the north side up. (d) Aftershocks within a day of the main shock occurrence are indicated by open circles. The locations of aftershocks were determined by Ratchkovski et al. (2003). 

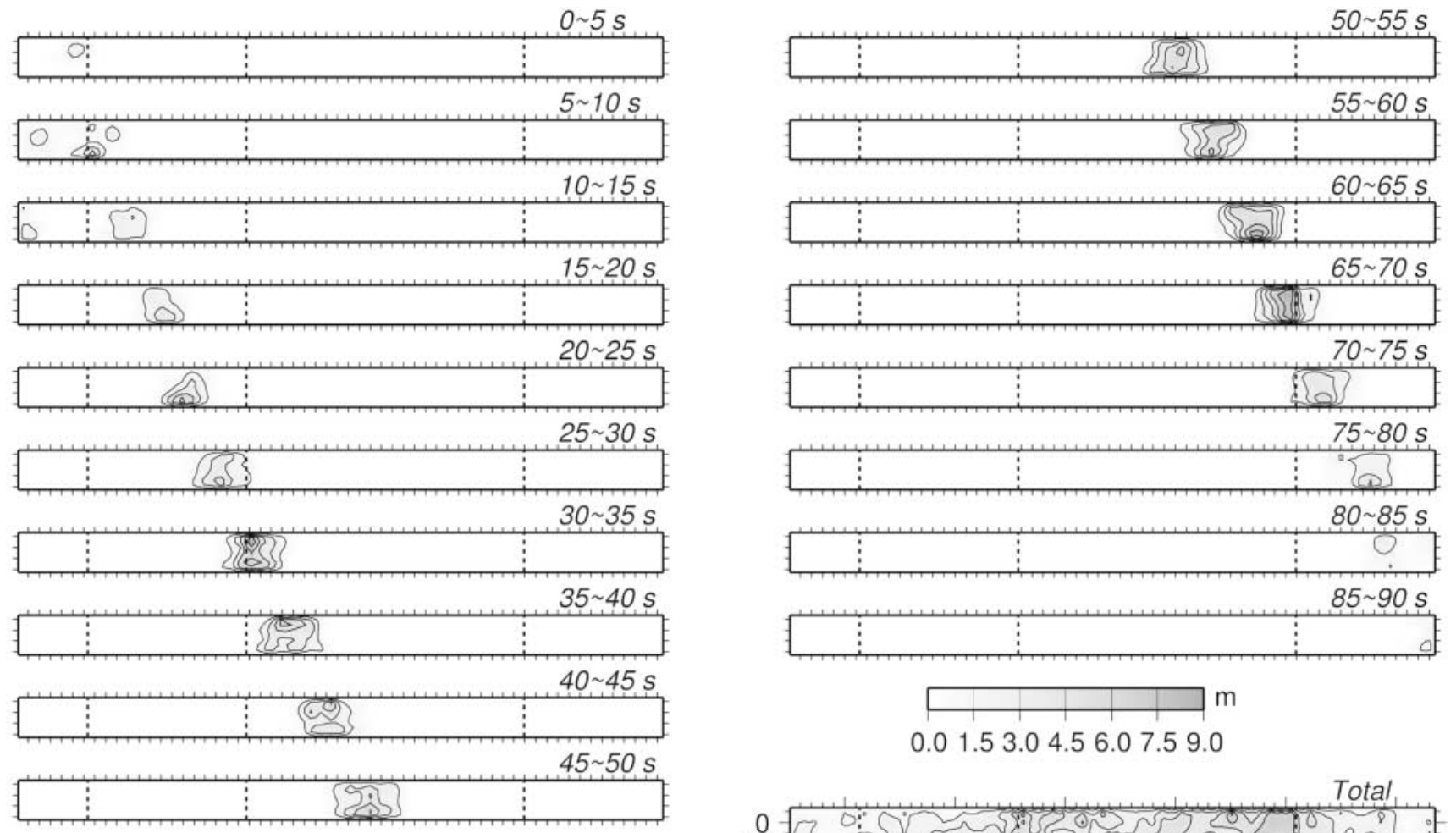

0.01 .53 .04 .56 .07 .59 .0

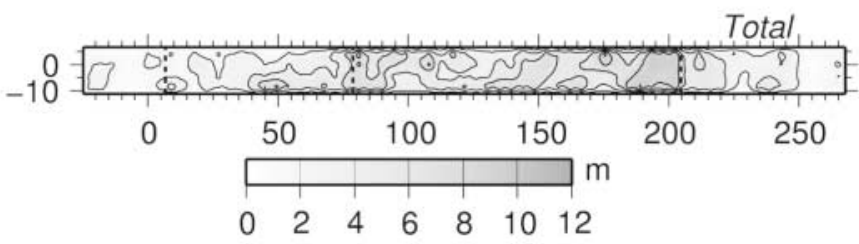

Figure 6. Temporal evolution of the rupture in terms of slip.

near the epicenter is almost a pure dip slip, and the main part of the rupture has a strike-slip motion. The total seismic moment of this source model is $7.57 \times 10^{20} \mathrm{Nm}\left(M_{\mathrm{W}} 7.9\right)$. The maximum and average slips are 10.57 and $4.25 \mathrm{~m}$, respectively.

Sekiguchi et al. (2000) demonstrated the variation of final slip on the fault with different smoothing strengths in the case of the 1995 Hyogo-ken Nanbu, Japan, earthquake. In Figure 7, the variation of final slip on the fault plane with different smoothing strengths $\lambda_{S}$ in our study are shown. This figure also shows the variation of ABIC values with different hyperparameters $\lambda_{S}$ and $\lambda_{H}$. To minimize the ABIC value given in equation (9), the two hyperparameters $\lambda_{S}$ and $\lambda_{H}$ in equation (8) were selected to be 0.07 and 3.5 , respectively.

As already mentioned above, the 2002 Denali earthquake exhibits the possibility of localized supershear rupture propagation (Ellsworth et al., 2004). Figure 5b shows the variation of the local rupture propagation velocity along the strike estimated by our source model. Here, the rupture time is defined as the time when the slip amount averaged over the depth at that portion reaches $0.4 \mathrm{~m}$, which is approximately $10 \%$ of the average slip over the fault plane. The local rupture propagation velocity is defined by the subfault length over the difference of the rupture time between subfaults. The local rupture propagation velocity on the TC seg- ment might not be constrained well because of the lack of a strong-motion station in that area. The estimated local rupture propagation velocity between the hypocenter and $65 \mathrm{~km}$ east from the hypocenter is relatively lower than that in the other part of the fault. The average rupture propagation velocity is about $3.4 \mathrm{~km} / \mathrm{sec}$ in the region between $65 \mathrm{~km}$ east from the hypocenter and the junction of the Denali and Totschunda faults, which does not exceed the shear-wave velocity in the source region $(\beta=3.4-3.6 \mathrm{~km} / \mathrm{sec})$. However, the supershear rupture propagation velocity is locally observed in our result at 70-80 km east and $120-145 \mathrm{~km}$ east from the hypocenter. The places showing supershear rupture propagation velocity are located just before or in the vicinity of the starting point of the large slip area. Fukuyama and Olsen (2002) have numerically studied the condition for exciting supershear rupture propagation in a heterogeneous stress field including an asperity of increased initial stress on a fault plane. They concluded that when the asperity is narrower than the critical size of the asperity, which is related to the critical slip-weakening distance $D_{C}$, it becomes difficult to continue supershear rupture propagation outside the asperity, even if the rupture propagation velocity jumps to supershear values for a short distance inside the asperity. This might be one interpretation of the locally excited supershear rupture in the case of the 2002 Denali earthquake. In 

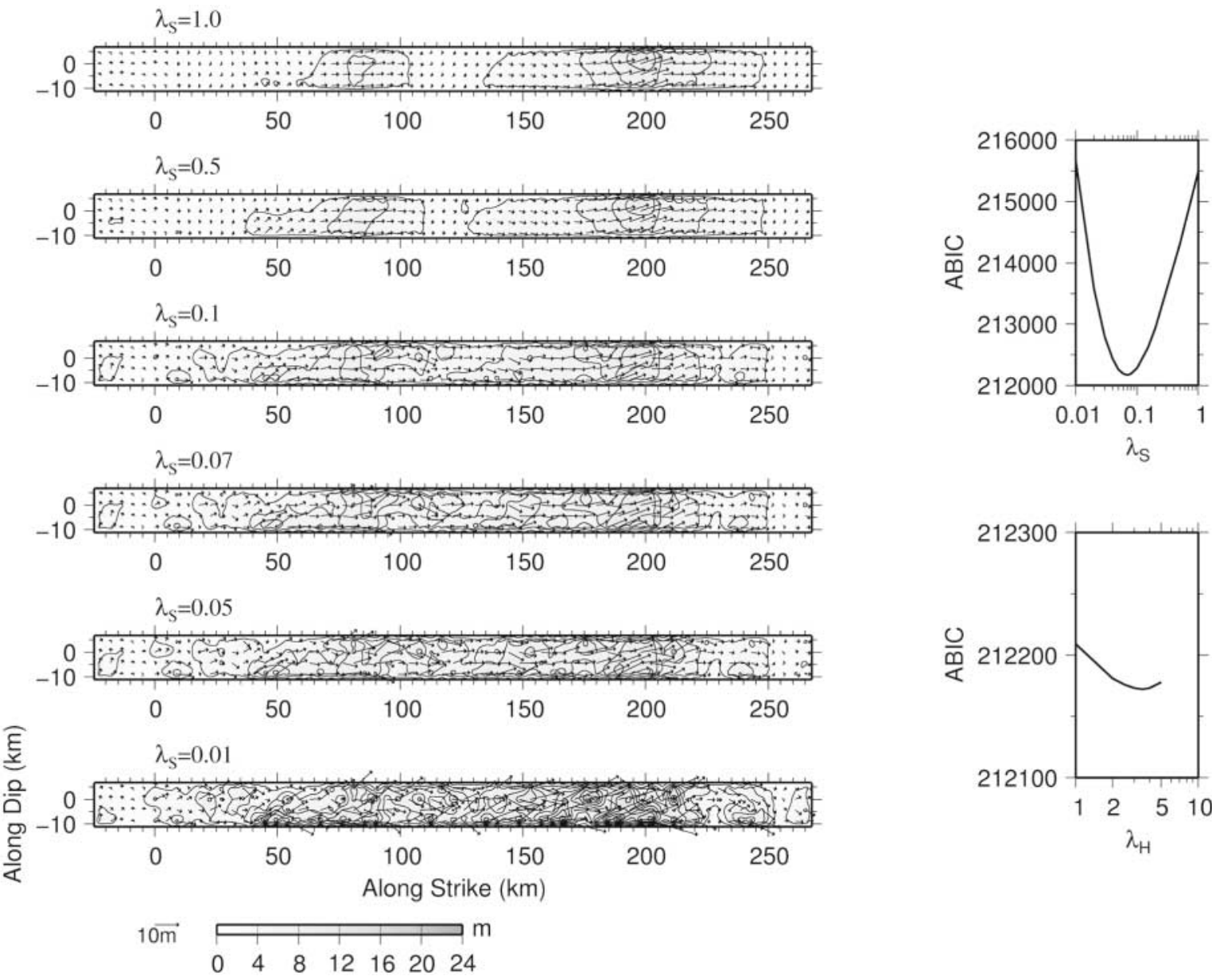

Figure 7. (left) The variation of final slip distribution on the fault plane with different smoothing strengths $\lambda_{S}$. The interval between the contours is $2 \mathrm{~m}$. (right) The variation of ABIC due to two hyperparameters $\lambda_{S}$ and $\lambda_{H}$. In the upper figure, $\lambda_{H}$ is fixed at 3.5. In the bottom figure, $\lambda_{S}$ is fixed at 0.07 .

order to investigate in detail the excitation of supershear rupture, more studies on the rupture dynamics of the 2002 Denali earthquake are required.

The waveforms at strong-motion stations (Fig. 8) fit fairly well. The waveforms at PS10, which is the nearest station to the fault and located in a forward direction, are particularly well simulated. However, the fit for all the components in the later phase at PS09 is not as good. The station PS09 is thought to be located inside a large basin structure called the Yukon-Tanana Terrane (Brocher et al., 1991), and this underground structure might generally produce a longperiod surface wave related to the three-dimensional structure, which is not assumed in our one-dimensional underground structure model. To quantitatively evaluate the effect of the three-dimensional structure, further detailed investigations into the underground structure around PS09 are required. The comparison between the observed and synthetic horizontal displacements at GPS stations is shown in Figure 9. The largest measured horizontal displacement of $3.107 \pm$ $0.004 \mathrm{~m}$ was observed at Mentasta (MEN) by Hreinsdóttir et al. (2003). The synthetic displacement matches well with such a large displacement.

\section{Discussion}

\section{Comparison with Other Information}

Figure 5c shows a comparison of the amount of slip at the shallowest subfaults with the observed surface offset. Surface rupture information is obtained from the report by Eberhart-Phillips et al. (2003). Eberhart-Phillips et al. (2003) searched for and mapped the surface ruptures in the 10 days following 3 November 2002, and they collected 129 measurements of fault scarp height and offset. Our source model is in good agreement with the features of surface rupture distribution. The correlation between the measured surface offset and the slip amount on the shallower part of the detailed inverted source model has been observed for recent events, for example, the 1995 Hyogo-ken Nanbu (Kobe), Japan, earthquake (Sekiguchi et al., 2000), the 1999 Kocaeli, 


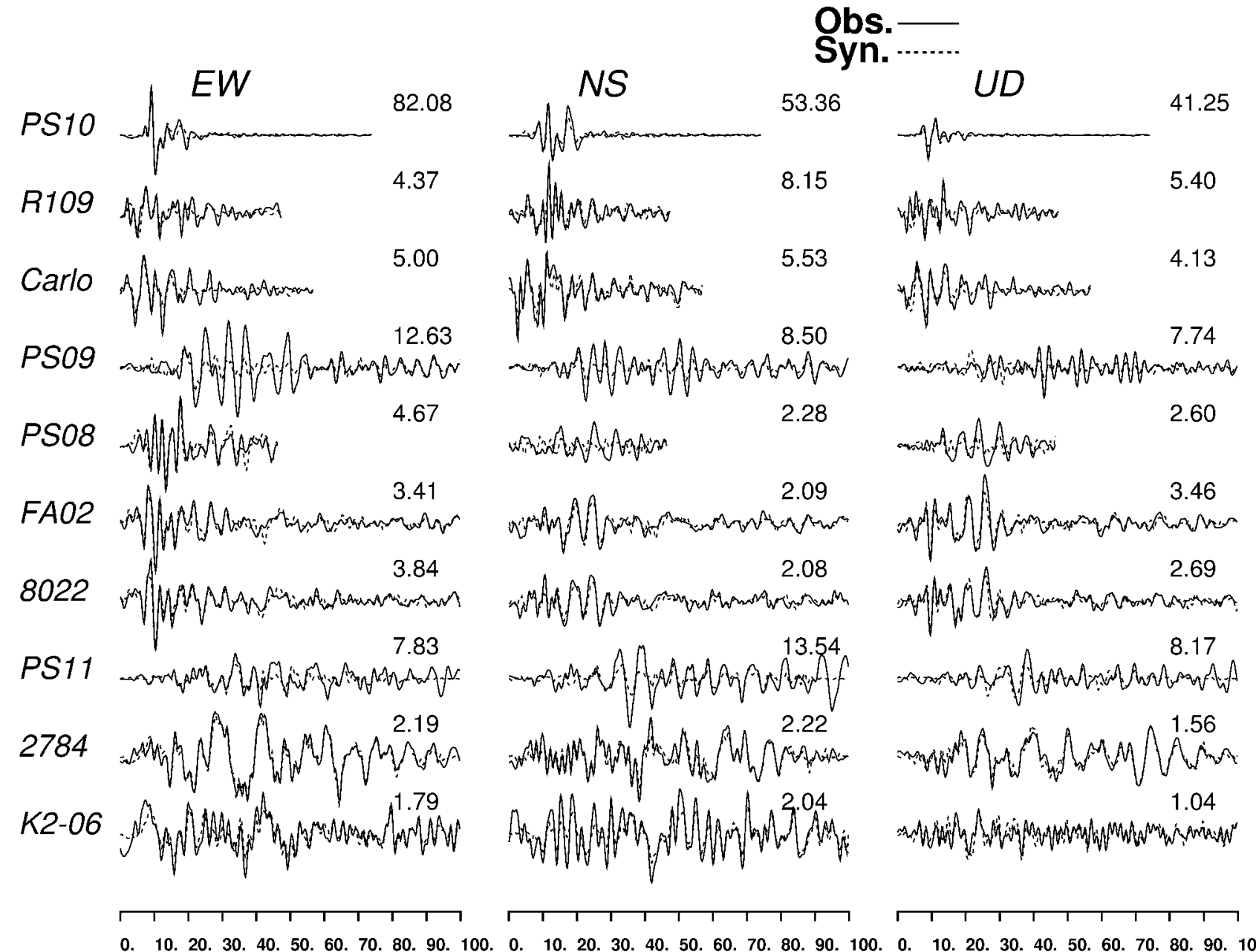

Figure 8. Comparison of observed (solid lines) and synthetic (broken lines) velocity waveforms at the strong motion stations. The number beside each trace indicates the maximum amplitude of the observed velocity in $\mathrm{cm} / \mathrm{sec}$.

Turkey, earthquake (Sekiguchi and Iwata, 2002), and the 1999 Chi-Chi, Taiwan, earthquake (Sekiguchi and Iwata, 2001). This implies that the information regarding active faults with surface slips accumulated from repeated earthquakes, can be used to characterize the heterogeneous rupture process of the source. The aftershocks within a day of the mainshock are also plotted in Figure 5d. Most aftershocks occurred at a depth of less than $15 \mathrm{~km}$, and the large slip areas have few aftershocks.

For this event, several results of source modeling using different methodologies and data sets are also available. For example, Kikuchi and Yamanaka (2002) have estimated the source model of this event by iterative deconvolution of teleseismic body waves. They concluded that the two subevents were derived and that the mechanisms of the first event near the epicenter and that of the second event located about $180 \mathrm{~km}$ east of the epicenter were completely different. The first event is a reverse fault striking northeast-southwest, and the second is a right-lateral strike-slip (Kikuchi and Yamanaka, 2002). The mechanism of the first event according to their result was quite similar to the focal mechanism determined from the polarities of $P$-wave first motions (Ratchkovski et al., 2002) and the field observational report by Eberhart-Phillips et al. (2003). Our inversion result using strong-motion and GPS data also suggests the same feature, and the spatial and temporal slip distribution of the inverted source model is more detailed than that obtained by inverting the teleseismic body waves. The seismic moment obtained by Kikuchi and Yamanaka (2002) is $7.8 \times 10^{20} \mathrm{Nm}\left(M_{\mathrm{W}}\right.$ 7.9), which is quite similar to our result. That implies that our assumption of the velocity structure is not inappropriate in the frequency range used.

Hreinsdóttir et al. (2003) also obtained a coseismic slip model by means of inverting the GPS-measured displacement field. They calculated Green's functions at GPS stations assuming an elastic half-space and a Poisson's ratio of 0.25 using the methodology described by Okada (1985). The seismic moment they obtained is $5.8 \times 10^{20} \mathrm{Nm}\left(M_{\mathrm{W}} 7.8\right)$, which is slightly smaller than our result and that obtained by teleseismic data. They resolved the high coseismic slip 


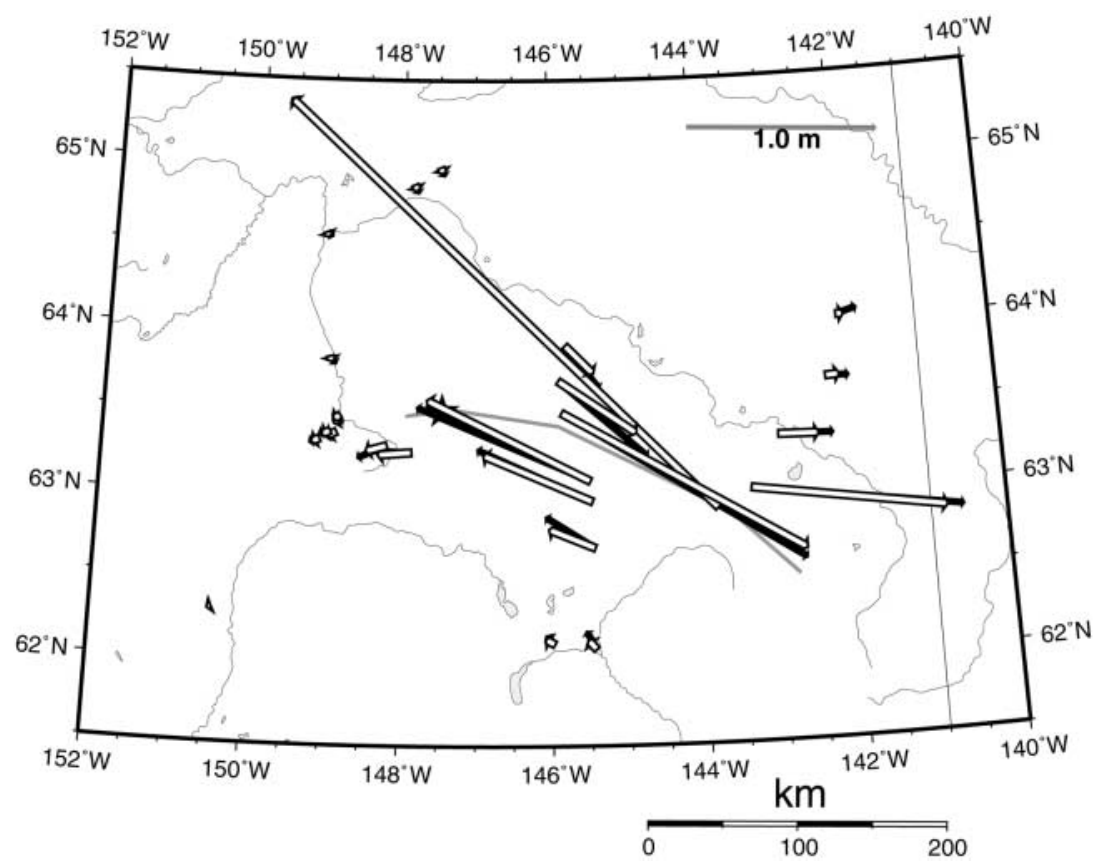

Figure 9. Comparison of observed (solid vectors) and synthetic (open vectors) static displacements at GPS stations. from approximately $60 \mathrm{~km}$ east of the hypocenter extending to the junction of the Denali and Totschunda faults. According to the conclusion by Hreinsdóttir et al. (2003), most slips are found at a shallow depth of less than $15 \mathrm{~km}$. That depth is consistent with that of the seismogenic layer that has been inferred from the occurrence of aftershocks. However, their inversion also suggests one large, deep slip patch approximately $110 \mathrm{~km}$ east of the hypocenter. In contrast to their result, our result did not show such an obvious large slip at the point mentioned.

Strong-motion records have also been adopted to study the source rupture process by several authors (e.g., Dreger et al., 2004; Frankel, 2004; Oglesby et al., 2004). Frankel (2004) inverted the displacement waveforms at strongmotion stations to estimate the moment release distribution of a line source model. Oglesby et al. (2004) studied the kinematic inversion using a combination of displacement waveforms at strong-motion stations, except PS10, and GPSmeasured displacement data, with the constraint that the top row of the model must match the observed surface offsets. The features of source rupture process observed in both models are consistent with our source model. The slip direction on the Susitna Glacier fault segment is a reverse motion, and two strike-slip major subevents are found along the Denali and Totschunda faults. One is the localized subevent near PS10, and the other is the largest subevent just before the junction between the Denali and Totschunda faults. Frankel (2004) also observed a supershear rupture velocity $(\sim 5.0$ $\mathrm{km} / \mathrm{sec}$ ) along the Denali fault. The average rupture velocity was $3.5 \mathrm{~km} / \mathrm{sec}$ (Frankel, 2004) or $3.3 \mathrm{~km} / \mathrm{sec}$ (Oglesby et al., 2004), values close to that of our model. Dunham and Archuleta (2004) concluded that the recordings of this earthquake provided evidence of supershear rupture velocity past
PS10 by spontaneous rupture propagation modeling. Their study supports our result presented earlier that the rupture propagation near PS10 was supershear. There are still several differences between our study and that of Oglesby et al. (2004). For instance. we did not use the observed surface offset distribution as the constraining information in the waveform inversion, whereas the obtained slips on the shallowest subfaults coincide with the observed surface offsets well (see Fig. 5c). Though Oglesby et al. (2004) mentioned a possibility of a small rupture jumping from the Denali to the Totschunda fault, we did not test such a case.

\section{Scaling Relationships for Great Inland Crustal Earthquakes}

Empirical scaling relationships between seismic moment and source parameters have been developed on the basis of seismological observations and theoretical source models in numerous studies (e.g., Kanamori and Anderson, 1975; Geller, 1976). Recently, heterogeneous source models derived from the waveform inversions using near-source strong-motion records have become available to study the relationships between source parameters. Somerville et al. (1999) have characterized the heterogeneous slip models of 15 shallow inland crustal earthquakes, which were derived from the inversion of near-source strong-motion records and teleseismic body waves, in a deterministic manner. Further, assuming a self-similar scaling model, they developed the scaling relationships between the parameters of the characterized slip models including asperities and seismic moments. Miyakoshi (2002) confirmed that the recently analyzed events also followed the relationships proposed by Somerville et al. (1999) up to a moment magnitude of 7.6. 
However, there have been few available great earthquakes with inverted source models based on instrumental records. On the other hand, Wells and Coppersmith (1994) compiled source parameters for historical earthquakes worldwide since the 1906 San Francisco earthquake in order to develop an empirical relationship between moment magnitude and rupture area estimated by the aftershock distributions, field investigations, and geodetic modeling. Irikura and Miyake (2001) discussed the relationship of large crustal earthquakes between seismic moments and rupture area by combining the data set compiled by Somerville et al. (1999) and Miyakoshi (2002) and a subset of the data compiled by Wells and Coppersmith (1994). They pointed out that the total rupture area followed the self-similar scaling relation with seismic moments for moderate-size $\left(M_{\mathrm{W}}<6.52\right)$ crustal earthquakes and departed from the self-similar model for very large crustal earthquakes. Hanks and Bakun (2002) also studied the scaling relationship of the rupture area with seismic moments using the data of strike-slip earthquakes of Wells and Coppersmith (1994) and five additional great continental strike-slip earthquakes. They proposed a bilinear scaling model wherein the relationship follows the self-similar source model for an event smaller than $M_{\mathrm{W}}=6.71$, and follows the $L$-model scaling, for which the average faulting displacement increases with fault length (e.g., Scholz, 1982), for events larger than $M_{\mathrm{W}}=6.71$. The 2002 Denali earthquake plays an important role in confirming whether the inverted source model based on observed instrumental records follows the systematic bilinear trend indicated by Hanks and Bakun (2002). As shown in Figure 10a, the total rupture area of the 2002 Denali earthquake obtained in this study is $5265 \mathrm{~km}^{2}$. This appears to follow the $L$-model scaling rather than the self-similar scaling model.

The asperities of our inverted source model are also characterized in the same manner as described by Somerville et al. (1999) (Miyakoshi, personal comm., 2004). The combined area of asperities is $648.0 \mathrm{~km}^{2}$, and the average slip of the asperities is $7.83 \mathrm{~m}$ (Fig. 10b). The asperities occupy only approximately $12 \%$ of the rupture area, which is smaller than the empirical value of $22 \%$ obtained by Somerville et $a l$. (1999). It should be noted that the large slip that mainly controls the ground motion at PS10 is not picked out as an asperity in this manner.

\section{Ground Motion Simulation using the Finite Difference Method}

In order to evaluate the influence of the heterogeneous source process on surface ground motions, we carried out a ground motion simulation in a one-dimensional underground structure assuming the source process obtained from the inversion of strong motion and GPS data. The ground motions were calculated using the finite difference method developed by Pitarka (1999). We have modeled the volumetric area of $480 \times 360 \times 42 \mathrm{~km}^{3}$ so as to include the ruptured fault. The grid dimensions are $801 \times 601 \times 71$

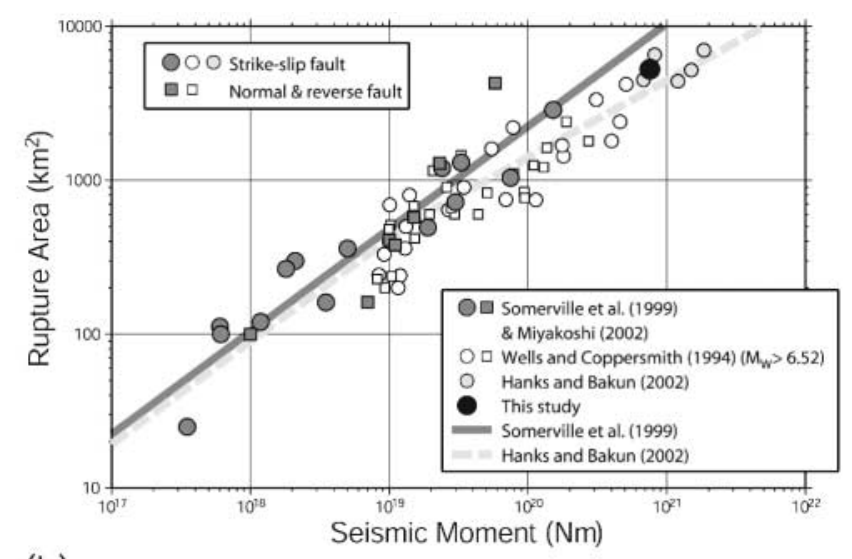

(b)

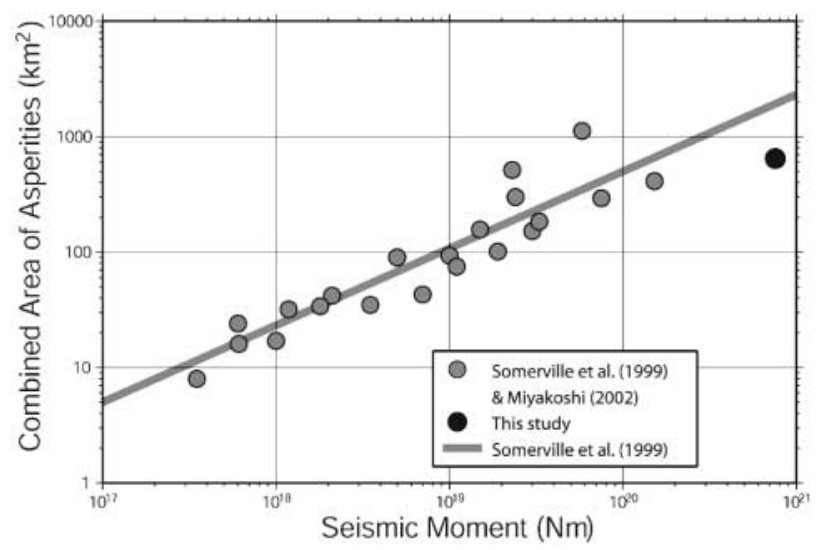

Figure 10. (a) Relationship between rupture area and seismic moment. The solid line is the empirical relationship of the self-similar source model proposed by Somerville et al. (1999). The broken line denotes the bilinear scaling model for strike-slip earthquakes proposed by Hanks and Bakun (2002). (b) Relationship between combined area of asperities and seismic moment. The solid line denotes the empirical relationship proposed by Somerville et al. (1999).

grids with a grid spacing of $600 \mathrm{~m}$. The time increment in the finite difference calculation is $0.028960 \mathrm{sec}$. The total number of time increments is 5180 , which corresponds to the time history of $150 \mathrm{sec}$. This calculation is valid up to $0.5 \mathrm{~Hz}$. The one-dimensional underground structure is the same as that used for calculating Green's functions in the inversion analysis above. Figure 11 shows the spatial distributions of peak ground velocities (PGV) on the surface. The components shown in Figure 11 are $\mathrm{N} 28^{\circ} \mathrm{E}$ (almost faultnormal), $\mathrm{N} 118^{\circ} \mathrm{E}$ (almost fault-parallel), and the vertical components. In this figure, the synthetic ground motions are bandpass filtered between 0.05 and $0.5 \mathrm{~Hz}$. The surface ground motion in this calculation should be considered to approximate the bedrock ground motion because the $S$-wave velocity of the superficial layer is $2.2 \mathrm{~km} / \mathrm{sec}$. Fault-normal ground motions are relatively large above and around large slip areas, and these ground motions are mainly controlled by the nearest large slip. The result of the finite difference 


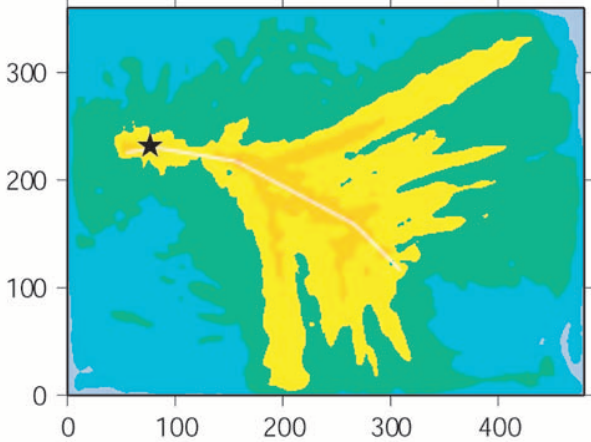

Vertical
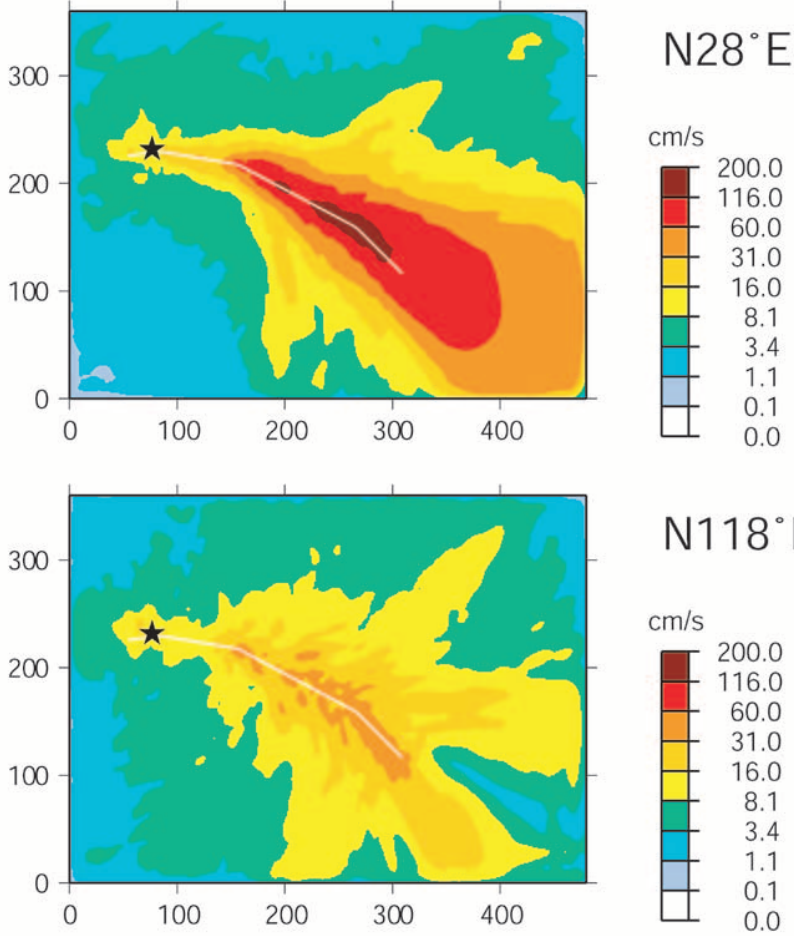

Figure 11. Maps showing the spatial distribution of peak ground velocities calculated by the finite difference method. Upper, middle, and lower maps show the vertical, $\mathrm{N} 28^{\circ} \mathrm{E}$ (fault-normal), and $\mathrm{N} 118^{\circ} \mathrm{E}$ (faultparallel) components, respectively. The assumed fault trace is indicated by the white line.

calculation also shows an area having a relatively large PGV extending to the east of the Totschunda fault. A simple explanation for this phenomenon is the forward directivity effect related to the rupture propagation along the very long strike from west to east.

The Community Internet Intensity Map (CIIM) for the 2002 Denali earthquake, produced by the USGS, is shown in Figure 12. The rectangular area indicated in Figure 12 is the target area for the finite difference calculation. The CIIM is a compilation of questionnaire survey data regarding seismic intensities obtained using the Internet (Wald et al., 1999a). In the CIIM, each community, which is defined by the geographic boundaries of 5-digit ZIP codes, has one representative intensity based on the statistics compiled from several
Community Internet Intensity Map (47 miles E of Cantwell, Alaska) ID:22614036 13:12:41 AKST NOV 32002 Mag=7.9 Latitude=N63.52 Longitude=W147.46

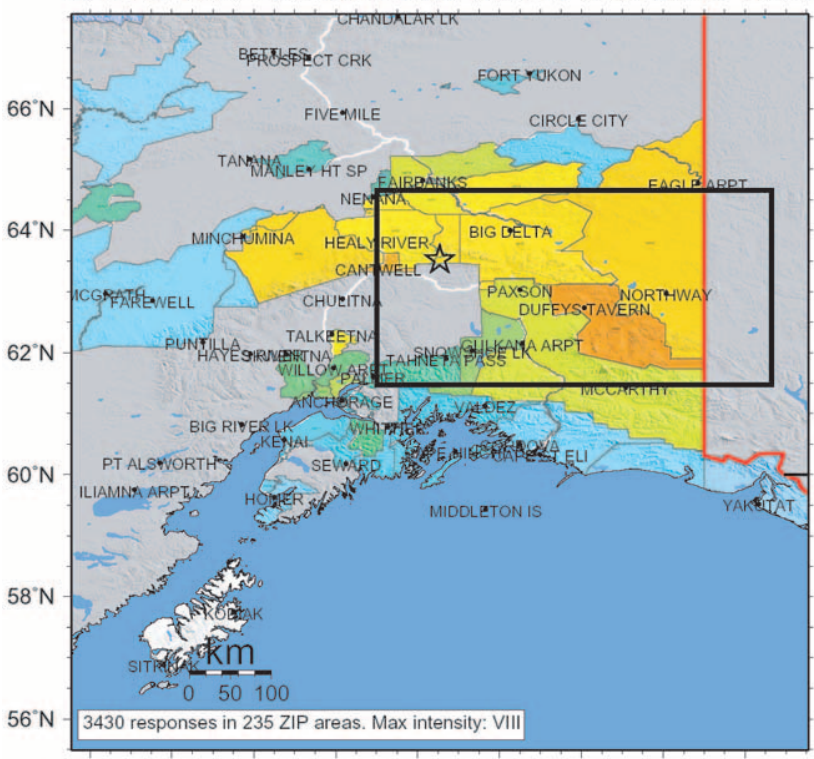

$156^{\circ} \mathrm{W} 154^{\circ} \mathrm{W} 152^{\circ} \mathrm{W} 150^{\circ} \mathrm{W} 148^{\circ} \mathrm{W} 146^{\circ} \mathrm{W} \quad 144^{\circ} \mathrm{W} \quad 142^{\circ} \mathrm{W} \quad 140^{\circ} \mathrm{W}$

\begin{tabular}{|c|c|c|c|c|c|c|c|c|c|}
\hline INTENSITY & I & II-III & IV & V & VI & VII & VIII & IX & $X+$ \\
\hline SHARING & Not felt & Weak & Light & Moderate & Strong & Very strong & Severe & Violent & Extreme \\
\hline DAMAGE & none & none & none & Very light & Light & Moderate & Moderate Heavy & Heavy & Very Heary \\
\hline
\end{tabular}

Figure 12. Community Internet Intensity Map by the USGS (Wald et al., 1999a). This map is available on the Internet at the USGS Web site (http://pasadena.wr.usgs.gov/ shake/ak/STORE/X22614036/ciim_display.html).

reports. The maximum intensity VIII on the Modified Mercalli Intensity (MMI) scale was reported at the Gakona community, east of the Totschunda fault. Intensity VIII in the MMI scale corresponds to a PGV of $0.31-0.60 \mathrm{~m} / \mathrm{sec}$ (Wald et al., 1999b). While it must be remembered that the frequency range for the finite difference calculation is limited to between 0.05 and $0.5 \mathrm{~Hz}$, the area of large PGV as per the results of the finite difference calculation appears to roughly correlate with the large intensity area on the CIIM. This suggests the importance of spatial rupture heterogeneity on surface ground motions.

\section{Conclusions}

The source process of the Denali fault earthquake that occurred on 3 November 2002 were studied through a multiple time-window linear kinematic waveform inversion using strong motion and GPS data. A source model that agreed with the observed strong motion waveforms and GPSmeasured horizontal displacements was obtained. Large slips on the fault plane were observed at approximately 80 $90 \mathrm{~km}$ east and approximatelty 150-200 km east of the hypocenter. This inverted source model is also consistent with observed surface ruptures and other source models estimated from teleseismic and geodetic data. The inverted source model provides more detailed spatial and temporal infor- 
mation than that obtained from teleseismic body waves and geodetic data. The average rupture propagation velocity at the main part of the rupture was about $3.4 \mathrm{~km} / \mathrm{sec}$. However, the rupture propagation velocity locally exceeded the shearwave velocity at approximately $70-80 \mathrm{~km}$ east and approximately $120-145 \mathrm{~km}$ east from the epicenter. This study also shows that the total rupture area appears to follow $L$-model scaling. The heterogeneous source process of the 2002 Denali earthquake brought about strong ground motions above and around the large slip area and the region east of the source area.

\section{Acknowledgments}

Digital strong-motion records used in this study were released by the United States Geological Survey, the University of Alaska at Fairbanks, and the Alyeska Pipeline Service Company. Hypocentral information was obtained from the Alaska Earthquake Information Center. We sincerely thank Dr. Haruko Sekiguchi at the Active Fault Research Center, National Institute of Advanced Industrial Science and Technology, Japan, for allowing us to use her codes of the multiple time-window linear kinematic waveform inversion, and Dr. Arben Pitarka at the URS Corporation for allowing us to use his codes of the finite difference method. We also thank Dr. Ken Miyakoshi at the Geo-Research Institute, Osaka, Japan, for estimating total rupture area and asperity area from our inverted source slip model following Somerville's criterion, and Dr. Hiroe Miyake at the Earthquake Research Institute, University of Tokyo, for helping us with regard to source scaling models. We are deeply grateful to Prof. Igor Beresnev, Dr. Andrew Michael, Dr. Pengcheng Liu, and an anonymous reviewer for their suggestions on improving this article. We used Generic Mapping Tools (Wessel and Smith, 1998) to draw several figures in this article. This study was supported by the special project for earthquake disaster mitigation in urban areas of the Ministry of Education, Culture, Sports, Science, and Technology, Japan

\section{References}

Akaike, H. (1980). Likelihood and the Bayes procedure, in Bayesian Statistics, J. M. Bernardo, M. H. DeGroot, D. V. Lindley, and A. F. M. Smith (Editors), University Press, Valencia, Spain, 143-166.

Andrews, D. J. (1976). Rupture velocity of plane strain shear cracks, $J$. Geophys. Res. 81, 5679-5687.

Archuleta, R. J. (1984). A faulting model for the 1979 Imperial Valley earthquake, J. Geophys. Res. 89, 4559-4585.

Beaudoin, B. C., G. S. Fuis, W. D. Mooney, W. J. Nokleberg, and N. I. Christensen (1992). Thin, low-velocity crust beneath the Southern Yukon-Tanana Terrane, East Central Alaska: results from TransAlaska crustal transect refraction/wide-angle reflection data, J. Geophys. Res. 97, 1921-1942.

Boucher, C., Z. Altamimi, and P. Sillard (1999). The 1997 International Terrestrial Reference Frame (ITRF1997), IERS Tech. Note 27, Observatoire de Paris, Paris, France, $191 \mathrm{pp}$.

Bouchon, M. (1981). A simple method to calculate Green's functions for elastic layered media, Bull. Seism. Soc. Am. 71, 959-971.

Bouchon, M., and M. Vallée (2003). Observation of long supershear rupture during the magnitude 8.1 Kunlunshan earthquake, Science 301, 824826.

Bouchon, M., N. Toksöz, H. Karabulut, M.-P. Bouin, M. Dietrich, M. Aktar, and M. Edie (2000). Seismic imaging of the 1999 Izmit (Turkey) rupture inferred from the near-fault recordings, Geophys. Res. Lett. 27, 3013-3016.

Brocher, T. M., W. J. Nokleberg, N. I. Christensen, W. J. Lutter, E. L. Geist, and M. A. Fisher (1991). Seismic reflection/refraction mapping of faulting and regional dips in the Eastern Alaska Range, J. Geophys. Res. 96, 10,233-10,249.

Burridge, R. (1973). Admissible speeds for plane-strain self-similar shear cracks with friction but lacking cohesion, Geophys. J. Roy. Astr. Soc. 35, 439-455.

Burridge, R., and L. Knopoff (1964). Body force equivalents for seismic dislocations, Bull. Seism. Soc. Am. 54, 1875-1888.

Das, S., and K. Aki (1977). A numerical study of two-dimensional spontaneous rupture propagation, Geophys. J. Roy. Astr. Soc. 50, 643-668.

Day, S. M. (1982). Three-dimensional simulation of spontaneous rupture: the effect of nonuniform prestress, Bull. Seism. Soc. Am. 72, 18811902.

Dreger, D. S., D. D. Oglesby, R. Harris, N. Ratchkovski, and R. Hansen (2004). Kinematic and dynamic rupture models of the November 3, $2002 M_{\mathrm{W}} 7.9$ Denali, Alaska, earthquake, Geophys. Res. Lett. 31, L04605, doi 10.1029/2003GL018333.

Dunham, E. M., and R. J. Archuleta (2004). Evidence for a supershear transient during the 2002 Denali fault earthquake, Bull. Seism. Soc. Am. 94, S256-S268.

Eberhart-Phillips, D., P. J. Haeussler, J. T. Freymueller, A. D. Frankel, C. M. Rubin, P. Craw, N. A. Ratchkovski, G. Anderson, G. A. Carver, A. J. Crone, T. E. Dawson, H. Fletcher, R. Hansen, E. L. Harp, R. A. Harris, D. P. Hill, S. Hreinsdóttir, R. W. Jibson, L. M. Jones, R. Kayen, D. K. Keefer, C. F. Larsen, S. C. Moran, S. F. Personius, G. Plafker, B. Sherrod, K. Sieh, N. Sitar, and W. K. Wallace (2003). The 2002 Denali fault earthquake, Alaska: a large magnitude, slippartitioned event, Science 300, 1113-1118.

Ekström, G., A. M. Dziewoński, N. N. Maternovskaya, and M. Nettles (2005). Global seismicity of 2002: centroid-moment-tensor solutions for 1034 earthquakes, Phys. Earth Planet. Interiors 148, 303-326.

Ellsworth, W. L., and M. Çelebi (1999). Near field displacement time histories of the M 7.4 Kocaeli (Izmit), Turkey, earthquake of August 17, 1999, EOS 80, Fall Meet. Suppl., F648.

Ellsworth, W. L., M. Çelebi, J. R. Evans, E. G. Jensen, D. J. Nyman, and P. Spudich (2004). Processing and modeling of the pump station 10 record from the November 3, 2002 Denali fault, Alaska, earthquake, Proc. 11th Int'l Conf. Soil Dyn. Earthquake Eng. 1, 471-477.

Frankel, A. (2004). Rupture process of the M 7.9 Denali Fault, Alaska, earthquake: subevents, directivity, and scaling of high-frequency ground motions, Bull. Seism. Soc. Am. 94, S234-S255.

Fuis, G. S., and L. A. Wald (2003). Rupture in south-central Alaska? The Denali fault earthquake of 2002, U.S. Geol. Surv. Fact Sheet 014-03, 4 pp.

Fukuyama, E., and K. B. Olsen (2002). A condition for super-shear rupture propagation in a heterogeneous stress field, Pure Appl. Geophys. 159, 2047-2056.

Geller, R. J. (1976). Scaling relations for earthquake source parameters and magnitudes, Bull. Seism. Soc. Am. 66, 1501-1523.

Grantz, A. (1966). Strike-slip faults in Alaska, U.S. Geol. Surv. Open-File Rept. 66-53, 82 pp.

Graves, R. W., and D. J. Wald (2001). Resolution analysis of finite fault source inversion using one- and three-dimensional Green's functions, 1. Strong motions, J. Geophys. Res. 106, 8745-8766.

Hanks, T. C., and W. H. Bakun (2002). A bilinear source-scaling model for M-log A observations of continental earthquakes, Bull. Seism. Soc. Am. 92, 1841-1846.

Hartzell, S. H., and T. H. Heaton (1983). Inversion of strong ground motion and teleseismic waveform data for the fault rupture history of the 1979 Imperial Valley, California, earthquake, Bull. Seism. Soc. Am. 73, 1553-1583.

Hickman, R. G., C. Craddock, and K. W. Sherwood (1977). Structural geology of the Nenana Rover segment of the Denali fault system, central Alaska Range, Geol. Soc. Am. Bull. 88, 1217-1230.

Hreinsdóttir, S., J. T. Freymueller, H. J. Fletcher, C. F. Larsen, and R. Bürgmann (2003). Coseismic slip distribution of the $2002 M_{\mathrm{W}} 7.9$ Denali fault earthquake, Alaska, determined from GPS measurements, Geophys. Res. Lett. 30, 1670, doi:10.1029/2003GL017447. 
Irikura, K., and H. Miyake (2001). Prediction of strong ground motions for scenario earthquakes, J. Geogr. 110, 849-875 (in Japanese with English abstract).

Ji, C., Y. Tan, D. Helmberger, and J. Tromp (2003). Modeling teleseismic $\mathrm{P}$ and SH static offsets for great strike-slip earthquakes, EOS 84, Fall Meet. Suppl., F999.

Kanamori, H., and D. L. Anderson (1975). Theoretical basis of some empirical relations in seismology, Bull. Seism. Soc. Am. 65, 1073-1095.

Kennett, B. L. N., and N. J. Kerry (1979). Seismic waves in a stratified half space, Geophys. J. Roy. Astr. Soc. 57, 557-583.

Kikuchi, M., and Y. Yamanaka (2002). Source rupture processes of the central Alaska earthquake of Nov. 3, 2002, inferred from teleseismic body waves ( + the 10/23 M6.7 event), EIC Seismological Note, No. 129, wwweic.eri.u-tokyo.ac.jp/EIC/EIC_News/021103AL-e.html.

Lanphere, M. A. (1978). Displacement history of the Denali fault system, Alaska and Canada, Can. J. Earth Sci. 15, 817-822.

Lawson, C. L., and R. J. Hanson (1974). Solving Least Squares Problems, Prentice-Hall, New Jersey, 340 pp.

Martirosyan, A., R. Hansen, and N. Ratchkovski (2004). Strong-motion records of the 2002 Denali fault, Alaska, earthquake, Earthquake Spectra 20, 579-596.

Maruyama, T. (1963). On the force equivalents of dynamic elastic dislocations with reference to the earthquake mechanism, Bull. Earthquake Res. Inst., Univ. Tokyo 41, 467-486.

Miyakoshi, K. (2002). Characterization of heterogeneous source models, Chikyu Monthly, Special Edition 37, 56-61 (in Japanese).

Oglesby, D. D., D. S. Dreger, R. A. Harris, N. Ratchkovski, and R. Hansen (2004). Inverse kinematic and forward dyanamic models of the 2002 Denali Fault earthquake, Alaska, Bull. Seism. Soc. Am. 94, S214 S233.

Okada, Y. (1985). Surface deformation due to shear and tensile faults in a half-space, Bull. Seism. Soc. Am. 75, 1135-1154.

Olson, A. H., and R. J. Apsel (1982). Finite faults and inverse theory with applications to the 1979 Imperial Valley earthquake, Bull. Seism. Soc. Am. 72, 1969-2001.

Ozacar, A. A., S. L. Beck, and D. H. Christensen (2003). Source process of the 3 November 2002 Denali fault earthquake (central Alaska) from teleseismic observations, Geophys. Res. Lett. 30, 1638, doi:10.1029/ 2003GL017272.

Pitarka, A. (1999). 3D elastic finite-difference modeling of seismic motion using staggered grids with nonuniform spacing, Bull. Seism. Soc. Am. 89, 54-68.

Plafker, G., T. Hudson, and D. H. Richter (1977). Preliminary observations on late Cenozoic displacements along the Totschunda and Denali fault systems, U.S. Geol. Surv. Circ. 751-B, 67-69.

Ratchkovski, N. A., R. A. Hansen, D. Christensen, and K. Kore (2002). The 7.9 Denali fault earthquake: aftershock locations, moment tensors and focal mechanisms from the regional seismic network data, EOS 83, Fall. Meet. Suppl., Abstract S72F-1345.

Ratchkovski, N. A., R. A. Hansen, J. C. Stachnik, T. Cox, O. Fox, L. Rao, E. Clark, M. Lafevers, S. Estes, J. B. MacCormack, and T. Williams (2003). Aftershock sequence of the $M_{\mathrm{w}} 7.9$ Denali fault, Alaska, earthquake of 3 November, 2002 from regional seismic network data, Seism. Res. Lett. 74, 743-752.
Savage, J. C., and M. Lisowski (1991). Strain accumulation along the Denali fault at the Nenana River and Delta River crossings, Alaska, J. Geophys. Res. 96, 14,481-14,492.

Scholz, C. H. (1982). Scaling laws for large earthquakes: consequences for physical models, Bull. Seism. Soc. Am. 72, 1-14.

Sekiguchi, H., and T. Iwata (2001). The source process of the 1999 ChiChi, Taiwan, earthquake in semi-long period (2-20s), Annual Report on Active Fault and Paleoearthquake Researches, Geol. Surv. Japan, AIST 1, 315-324 (in Japanese with English abstract).

Sekiguchi, H., and T. Iwata (2002). Rupture process of the 1999 Kocaeli, Turkey, earthquake estimated from strong-motion waveforms, Bull. Seism. Soc. Am. 92, 300-311.

Sekiguchi, H., K. Irikura, and T. Iwata (2000). Fault geometry in the rupture termination of the 1995 Hyogo-ken Nanbu earthquake, Bull. Seism. Soc. Am. 90, 117-133.

Somerville, P., K. Irikura, R. Graves, S. Sawada, D. Wald, N. Abrahamson, Y. Iwasaki, T. Kagawa, N. Smith, and A. Kowada (1999). Characterizing crustal earthquake slip models for the prediction of strong ground motion, Seism. Res. Lett. 70, 59-80.

St. Amand, P. (1957). Geological and geophysical synthesis of the tectonics of portions of British Columbia, the Yukon Territory, and Alaska, Geol. Soc. Am. Bull. 68, 1343-1370.

Wald, D. J., and R. W. Graves (2001). Resolution analysis of finite fault source inversion using one- and three-dimensional Green's functions, 2. Combining seismic and geodetic data, J. Geophys. Res. 106, $8767-$ 8788.

Wald, D. J., and T. H. Heaton (1994). Spatial and temporal distribution of slip for the 1992 Landers, California, earthquake, Bull. Seism. Soc. Am. 84, 668-691.

Wald, D. J., V. Quitoriano, L. A. Dengler, and J. W. Dewey (1999a). Utilization of the Internet for Rapid Community Intensity Map, Seism. Res. Lett. 70, 680-697.

Wald, D. J., V. Quitoriano, T. H. Heaton, and H. Kanamori (1999b). Relationships between peak ground acceleration, peak ground velocity and Modified Mercalli Intensity in California, Earthquake Spectra 15, 537-556.

Wells, D. L., and K. J. Coppersmith (1994). New empirical relationships among magnitude, rupture length, rupture width, rupture area, and surface displacement, Bull. Seism. Soc. Am. 84, 974-1002.

Wessel, P., and W.H.F. Smith (1998). New, improved version of Generic Mapping Tools released, EOS 79, 579.

Wright, T. J., Z. Lu, and C. Wicks (2004). Constraining the slip distribution and fault geometry of the $M_{\mathrm{W}} 7.9,3$ November 2002, Denali Fault earthquake with Interferometric Synthetic Aperture Rader and Global Positioning System data, Bull. Seism. Soc. Am. 94, S175-S189.

Disaster Prevention Research Institute

Kyoto University

Gokasho, Uji

Kyoto 611-0011, Japan

k-asano@egmdpri01.dpri.kyoto-u.ac.jp

(K.A., T.I., K.I.)

Manuscript received 6 August 2004 